研究論文

\title{
MCNP コードの金属キャスク貯蔵方式中間貯蔵施設線量評価への適用
}

\author{
小佐古 敏荘 ${ }^{1}$, 飯本 武志 $^{1}$, 石川 智之 ${ }^{2, *}$, 坪井 孝文 ${ }^{2}$,

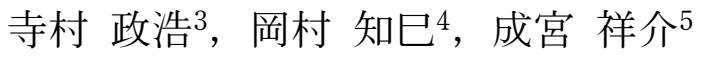

\author{
Application of Dose Evaluation of the MCNP Code for Interim Spent Fuel Cask Storage Facility

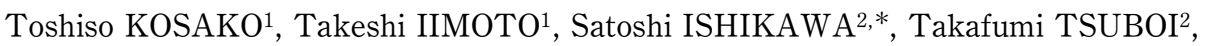 \\ Masahiro TERAMURA ${ }^{3}$, Tomomi OKAMURA ${ }^{4}$ and Yoshiyuki NARUMIYA ${ }^{5}$ \\ ${ }^{1}$ Tokyo University, 2-11-16 Yayoi, Bunkyo-ku, Tokyo 113-0032, Japan \\ ${ }^{2}$ ITOCHU Techno-Solutions Corp., 3-2-5 Kasumigaseki, Chiyoda-ku, Tokyo 100-6080, Japan \\ ${ }^{3}$ Toyo Engineering Corp., 2-8-1 Akanehama, Narashino-shi, Chiba 275-0024, Japan \\ ${ }^{4}$ The Tokyo Electric Power Co., Inc., 1-1-3 Uchisaiwai-cho, Chiyoda-ku, Tokyo 100-8560, Japan \\ ${ }^{5}$ The Kansai Electric Power Co., Inc., 3-6-16 Nakanoshima, Kita-ku, Osaka 530-8270, Japan
}

(Received August 30, 2006 and accepted in revised form January 22, 2007)

\begin{abstract}
The interim storage facility for spent fuel metallic cask is designed as a concrete building structure with air inlet and outlet for circulating the natural cooling. The feature of the interim storage facility is big capacity of spent fuel at several thousands MTU and restricted site usage. It is important to evaluate realistic dose rate in shielding design of the interim storage facility, therefore the three-dimensional continuous-energy Monte Carlo radiation transport code MCNP that exactly treating the complicated geometry was applied. The validation of dose evaluation for interim storage facility by MCNP code were performed by three kinds of neutron shielding benchmark experiments; cask shadow shielding experiment, duct streaming experiment and concrete deep penetration experiment. Dose rate distributions at each benchmark were measured and compared with the calculated results. The comparison showed a good consistency between calculation and experiment results.
\end{abstract}

\section{KEYWORDS: spent fuel cask storage, shielding benchmark experiment, duct streaming, cask shadow shielding, concrete deep penetration, Monte-Carlo, MCNP, neutron}

\section{I. 緒言}

国内で計画されている使用済燃料中間貯蔵施設 (以下, 「中間貯蔵施設」という。) は, 使用済燃料を輸送 · 貯蔵兼 用の金属キャスクに封入し，コンクリートを躯体とした建 屋の中で貯蔵する施設である。この金属キャスク貯蔵方式 を採用する中間貯蔵施設は，基本的に金属キャスクにより 安全性が担保されているが，貯蔵容量が数千 $\mathrm{t}$ と大規模な 施設となること, 現行の原子力施設(原子力発電所, 再処 理施設等)に比べ敷地境界が近いことから，金属キャスク からの放射線による一般公衆の線量評価では，建屋による

\footnotetext{
1 東京大学

2 伊藤忠テクノソリューションズ侏

3 東洋エンジニアリング侏

4 東京電力秼

5 関西電力秼

* Corresponding author, E-mail: satoshi.ishikawa@ctc-g.co.jp
}

C)Atomic Energy Society of Japan
補助的な遮へいを考慮する必要があり, 適切かつ合理的な 評価手法が求められる。

中間貯蔵施設の線量評価においては，金属キャスクが多 数離散的に配置されている問題や, 近い敷地境界のために 非常に厚くなる建屋の壁, 天井部のコンクリート遮へい, 金属キャスクの除熱のために建屋に開けられた大きな給排 口部からのストリーミングの問題を適切に評価しなければ ならない。これらの評価に, 現行の許認可申請等の遮へい 解析で使用されている 1 次元輸送計算コード ANISN1)や 2 次元輸送計算コード DOT $^{2}$ による 1 次元や 2 次元での 近似では適切なモデル化が難しいため, 計算結果が過大と なり，必要以上に建屋の壁や天井を厚くしたり，敷地境界 への距離を確保しなければならない可能性がある3)。この 問題を解決するため, 中間貯蔵施設の遮へい解析に 3 次 元形状の正確な取り扱いが可能な 3 次元モンテカルロ評 価手法を導入することを検討した。その結果, 3 次元モン テカルロ評価手法は, 現行の 1 次元や 2 次元計算コード 
に比べ，より現実的な評価が可能であり，精度検証等のい くつかの検討課題はあるものの, 敷地境界の線量に対して 寄与が大きい給排気口部ダクトストリーミングにおける中 性子の低減効果が顕著である等, 中間貯蔵施設における遮 へい設計の合理化に対して有効であるとの見通しが得られ た。

本研究では, 特に施設の遮へい構造の合理化に有効な中 性子に着目し, 3 次元モンテカルロ評価手法を中間貯蔵施 設の遮へい解析に適用することの妥当性を確認するため, 新たに中性子ベンチマーク実験の策定, 実験および実証解 析を実施した。使用した計算コードは，米国 Los Alamos 国立研究所 (LANL)に打いて開発された中性子, ガンマ線 および 2 次ガンマ線を対象とする汎用の 3 次元連続エネ ルギーモンテカルロ計算コード MCNP4,5) である。 MCNP コードは，米国の使用済燃料貯蔵施設の審査指針である NUREG-15676) に遮へ(解析ツールとして記載されてお り遮へい設計, 線量評価等で広く使用されている7 12)。

\section{MCNP コードによる線量評価の検討課題}

MCNP コードは，形状を忠実に模擬できるため，中間 貯蔵施設の線量評価においては, 建屋内に配列される金属 キャスクを, 線源であると同時に他のキャスクに対する遮 へい体(相互遮へい)として取り扱うことが可能となるとと もに，建屋の給排気口部からのダクトストリーミング解析 においては，ストリーミング線量の低減のために設置する 迷路構造などをモデル化することが可能となり，合理的な 遮へい設計を実現することができる。ただし，MCNP コードは，国内に抢ける許認可申請での使用実績が少ない こと, 相互遮へい効果や大口径のダクトストリーミングに 関する実験例が少ないことから，解析の妥当性を検証する 必要がある。また, 建屋の壁・天井部のコンクリートは, 敷地境界における線量の低減の観点から, 相当の厚さとな る可能性があり，コンクリートの深層透過に関する計算精 度の検証も必要である(第 1 図)。

\section{1. 相互遮へい効果}

中間貯蔵施設の線量評価では，金属キャスクの配列によ
る相互遮へい効果を考慮することが遮へい設計の合理化の 観点で有意と考えられる。ただ, 相互遮へい効果を考慮 した適切なベンチマーク実験が存在しないことから，金属 キャスクの相互遮へいによる線量低減効果抢よび解析の妥 当性について検証が必要である。また, 基本設計段階で行 う線量評価では，使用する金属キャスクが決まっていない 可能性があることや, 複数のキャスクを使用する場合には すべての金属キャスクの構造を忠実にモデル化することは 合理的ではないため, 安全裕度を考慮した適切な金属キャ スクのモデル化の検討が必要である。

\section{2. ダクトストリーミング}

中間貯蔵施設の場合，敷地境界までの距離が短いことか ら, 建屋の壁, 天井部のコンクリートが相当の厚さになる ため, バルク透過成分に比べて, 建屋の給排気口部(開口 部)からのストリーミング成分の寄与が大きくなると予想 される。現在計画中の中間貯蔵施設では, 開口部からのス トリーミング線量を低減するため, 建屋の給排気口部を迷 路構造や，コンクリート製のスリット板を設置するルー バー構造とすることが検討されている。しかしながら, 中 間貯蔵施設のように大口径のダクトストリーミングを対象 とした実験 ${ }^{13,14)}$ は少なく，かつ線量を低減するためのコン クリート製ルーバーによる遮へい実験は報告されていない ため, 解析の妥当性について検証が必要である。

\section{3. コンクリート深層透過}

コンクリートの深層透過については, 厚さ $60 \mathrm{~cm}$ まで のベンチマーク実験がこれまでに報告されている15)。し かしながら, 現在計画中の中間貯蔵施設では, 建屋の壁, 天井部のコンクリート厚は, $100 \mathrm{~cm}$ 程度となる可能性が あり,これらに対応する計算精度の検証が必要である。ま た，コンクリートは，その製造方法によって密度や元素組 成にばらつきがあり, 特に水素原子(水分)の含有量の差は 中性子の遮へい性能に大きく影響することから, 計算精度 検証に当たっては, 含有量の違いについても考慮する必要 がある。

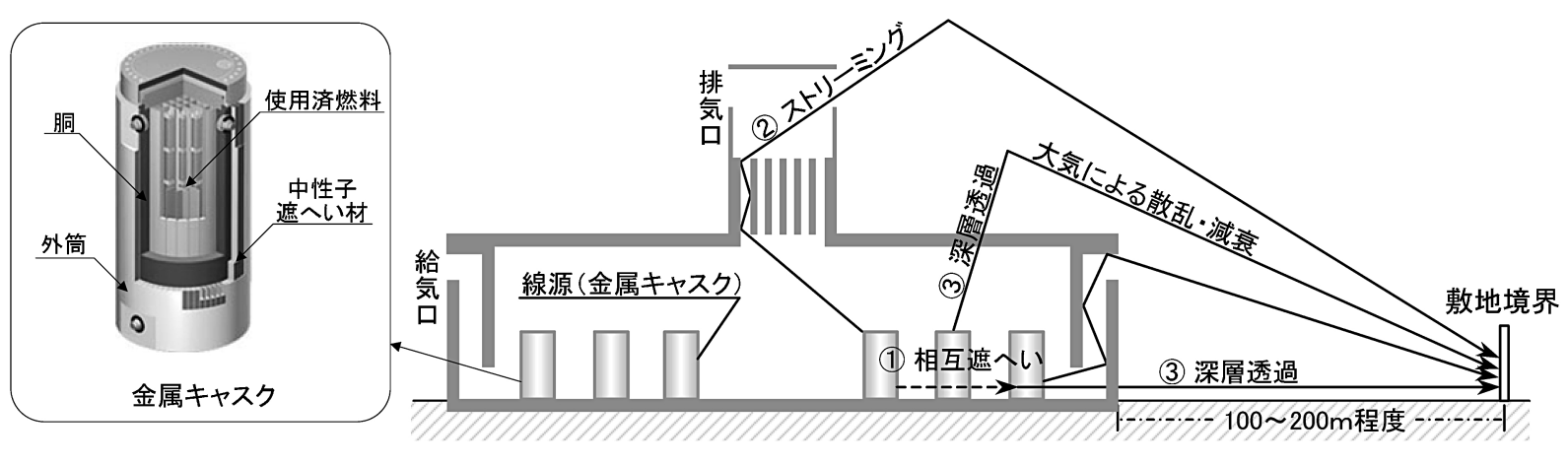

第 1 図 中間貯蔵施設に扔ける放射線経路 


\section{III. 実験の概要}

MCNP コードによる線量評価の検討課題を解決するた めに，新たに相互遮へい効果，ダクトストリーミングおよ びコンクリート深層透過の 3 つのベンチマーク実験につ いて実験計画を策定した。施設選定および予備解析を行っ た後, 実験を実施した。

\section{1. 実験施設}

中間貯蔵施設のキャスク配列や給排気口部を模擬するた めの十分な空間と中性子源を確保できる点からモスクワ物 理工科大学の研究用原子炉 IRT 炉で実験を実施した。 IRT 炉は，出力 $2.5 \mathrm{MW}$ の水プール型炬であり，本実験 で使用した水平実験孔の出口直径は $15 \mathrm{~cm}$ ，中心軸の高さ は床上 $87.5 \mathrm{~cm}$ である(第 2 図)。

\section{2. ビーム散乱体の設置}

相互遮へい効果実験およびダクトストリーミング実験の 線源は，中性子空間線量分布を確認する観点から，対象と する断面に対して線量率分布が平坦化していること，金属 キャスク表面のエネルギースペクトルに近似していること が望ましい。しかしながら, 水平実験孔の線源は, ビーム 状でかつ炉心のエネルギースペクトルであるため，ビーム 散乱体をビーム孔出口に設置し, 線量率分布の平坦化打よ びキャスク表面のエネルギースペクトルを模擬した。ビー ム散乱体は，高速中性子と熱中性子の遮へいに対応した鉄 とポリエチレンを組合せた対角面幅 $30 \mathrm{~cm}$ ，厚さ $35 \mathrm{~cm}$

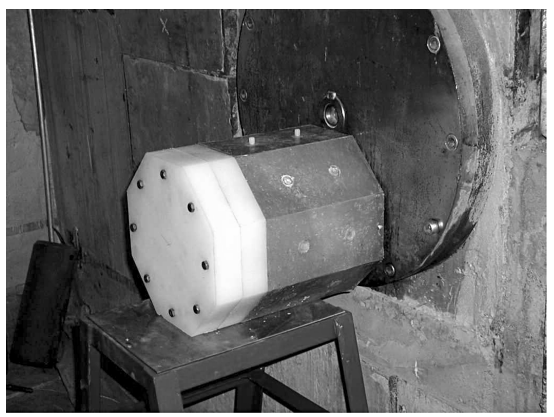

(a) ビーム散乱体

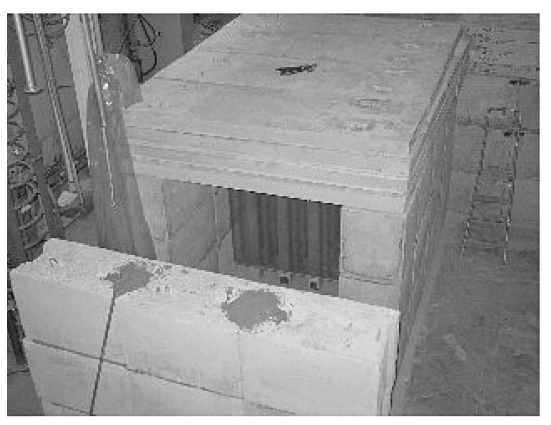

(c) ダクトストリーミング
の八角柱である(第 3 図 $(\mathrm{a}))$ 。

\section{3. 相互遮へ(効果実験}

実際の金属キャスクを $1 / 3$ スケールで模擬したキャスク (以下，「模擬キャスク」という。）を線源の周囲に格子状に 配列して，中性子線量などの低減効果を確認するための実 験を実施した。模擬キャスクを配列した外側周辺(以下， 「外縁部」という。）の測定位置等に抢ける中性子束や中性 子線量当量率を測定した。また, 特定位置での中性子エネ ルギースペクトルを測定した(第 3 図 $(b))$ 。

\section{4. ダクトストリーミング実験}

中間貯蔵施設の給排気口部のダクトおよびその内部に設 置するコンクリート製ルーバーを模擬したモデルを製作

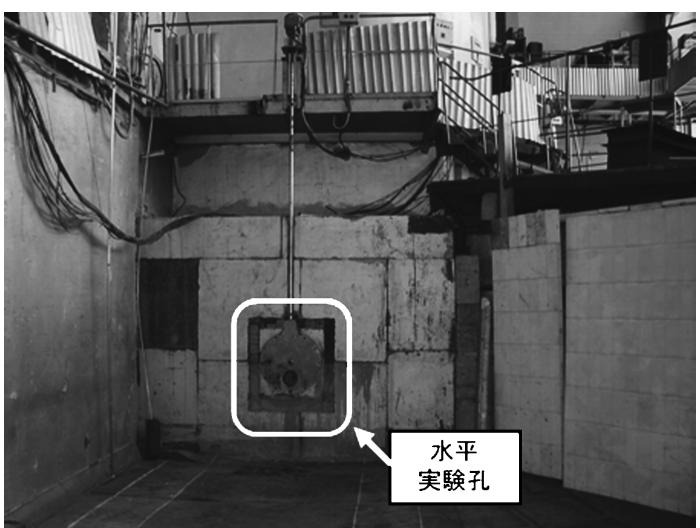

第 2 図 実験炉の概観および配置

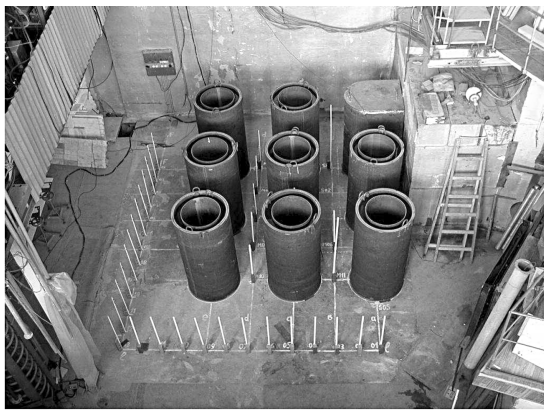

(b) キャスク相互遮へい

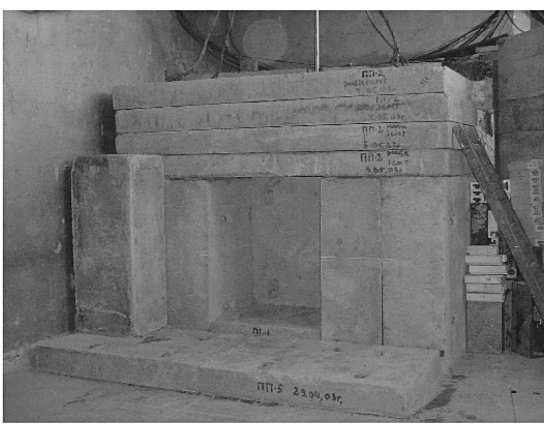

(d) コンクリート深層透過

第 3 図 各ベンチマーク実験風景 
し，迷路構造およびルーバーによるストリーミング線量の 低減効果を確認するための実験を実施した。ダクト内の中 心軸上抢よび断面内に測定位置を設定し, 中性子束と線量 の分布を測定した。またルルーバーによるストリーミング 線量の低減効果を確認するために，ルーバー前後の中性子 束と線量も測定した。あわせてダクト内主要点の中性子エ ネルギースペクトルを測定した(第 3 図(c))。

\section{5. コンクリート深層透過実験}

建屋の壁，天井部を模擬したコンクリート平板 (以下, 「平板供試体」という。)を実験孔出口に最大 $120 \mathrm{~cm}$ まで 積層して，中性子線量の減衰効果を確認するための実験を 実施した。積層するコンクリートの枚数を変化させ，コン クリート表面抢よび表面から $1 \mathrm{~m}$ (以下,「at $1 \mathrm{~m} 」$ という。) 位置での中性子線量当量率の測定を行った。コンクリート 表面では，中性子線量当量率分布を確認するため，ビーム 中心軸位置, そこから $25 \mathrm{~cm}$ 離れた位置にある上，下， 左抢よび右の 5 力所に測定点を設定した(第 3 図(d))。

\section{IV. 実験解析}

\section{1. 解析手法}

IRT 炉水平実験孔出口における中性子エネルギースペ クトルは，核分裂飛跡検出器により測定したデータをアン フォールディングすることにより求めた。計算に使用した 線源の中性子エネルギースペクトルを第 4 図に示す。ま た，ビーム孔から約 $4.2 \mathrm{~m}$ 離れた炉心に相当する位置に点 線源を設定し，ビームの拡がりを模擬した。 MCNP コー ドのバージョンは，MCNP 4 を採用した。断面積ライブ ラリーは，ENDF/B-VI をべースとして MCNP コード用 に作られた内蔵ライブラリーを用いた。エスティメータ は，レムカウンタと同じ大きさ(直径 $25.4 \mathrm{~cm}$ の球)の飛程 検出器評価法 (cell) 抢よび面検出器評価法 (surface) を使用 した。エスティメータの相対誤差(FSD)は，0.1未満を基 準とした ${ }^{4,5)}$ 。分散低減法は，モデル上の各領域のエネル ギー幅に対して設定を行う Weight Window 法を採用し た 4,5)。レムカウンタの中性子線量率変換係数には，ICRP，

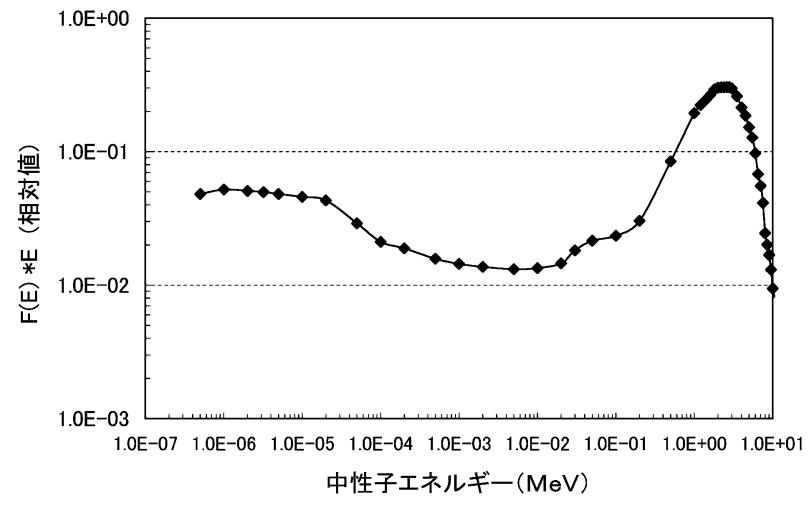

第 4 図 中性子エネルギースペクトル
Pub 51 対応の $1 \mathrm{~cm}$ 線量当量の値を採用した。

\section{2. 相互遮へ(効果実験解析}

\section{(1) 解析条件}

模擬キャスクの配列数，外筒厚さおよび配列間隔を变化 させた場合の各測定点でのレムカウンタによる中性子の 1 $\mathrm{cm}$ 線量当量率 (以下，「中性子線量率」という。)を評価し た。

線源部は，実験施設内でのガンマ線量率を低減するため にビーム散乱体全体を鉛で遮へいし，さらに鉄製半円筒の カバー(以下，「鉄製カバー」という。)で覆うことによって 実験孔からのビーム状の中性子を散乱させて, 強度分布が ほぼ均一となる円柱線源とした。ビーム散乱体モデルを第 5 図，鉛遮へい体付きビーム散乱体抢よび鉄製カバーモデ ルを第 6 図に示す。

模擬キャスクは, 直径 $90 \mathrm{~cm}$ 打よび高さ $180 \mathrm{~cm}$ の円環 タンク形状とし，外筒を鉄で，その内部に中性子遮へい材
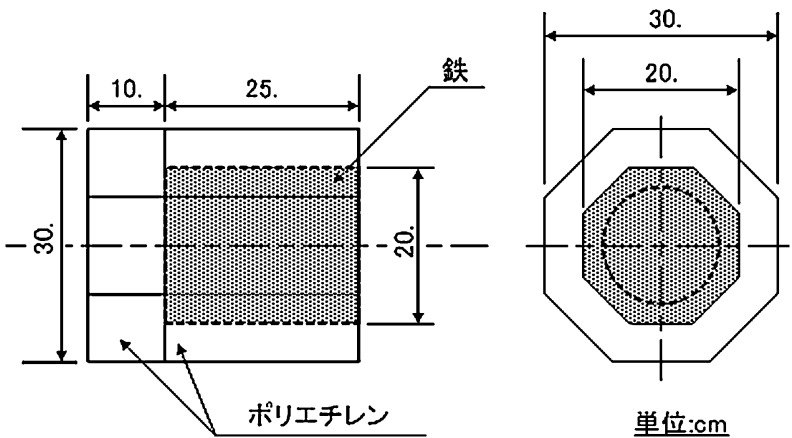

第 5 図 ビーム散乱体計算モデル

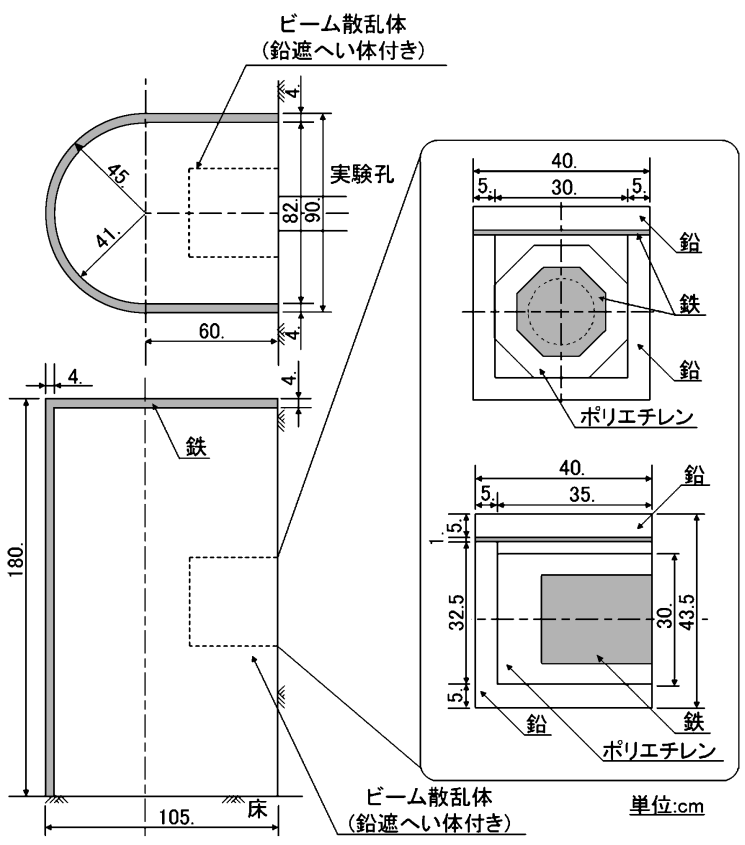

第 6 図鉛遮へい体付きビーム散乱体および鉄製カバー計算モ デル

日本原子力学会和文論文誌, Vol. 6, No. 2 (2007) 
として水を充填した。水の充填層厚さは, 予備解析の結果 により模擬キャスク表面の中性子の散乱や吸収に影響を与 えない厚さの $10 \mathrm{~cm}$ とした。模擬キャスクの外筒厚さ は, 金属キャスクの外筒厚さを考慮して $2 \mathrm{~cm}$ とし, 内側 に厚さ $2 \mathrm{~cm}$ の円柱殼状の板を追加できる構造とすること で, 合計 $4 \mathrm{~cm}$ 厚の外筒を模擬できる。模擬キャスクの計 算モデルを第 7 図, 模擬キャスクを 2 層配置した場合の 計算モデルを第 8 図に示す。鉄製カバーおよび模擬キャ スク (材質 : 炭素鋼), 並びにビーム散乱体 $($ 材質 : 鉄とポ リエチレン)の組成は化学分析值を用いた。計算に使用し た原子個数密度を第 1 表に示す。

計算ケースは，模擬キャスクの配列を「なし/1 層/2 層」 とした 3 ケースである。外筒厚さは $2 \mathrm{~cm}$ (基本ケース) と

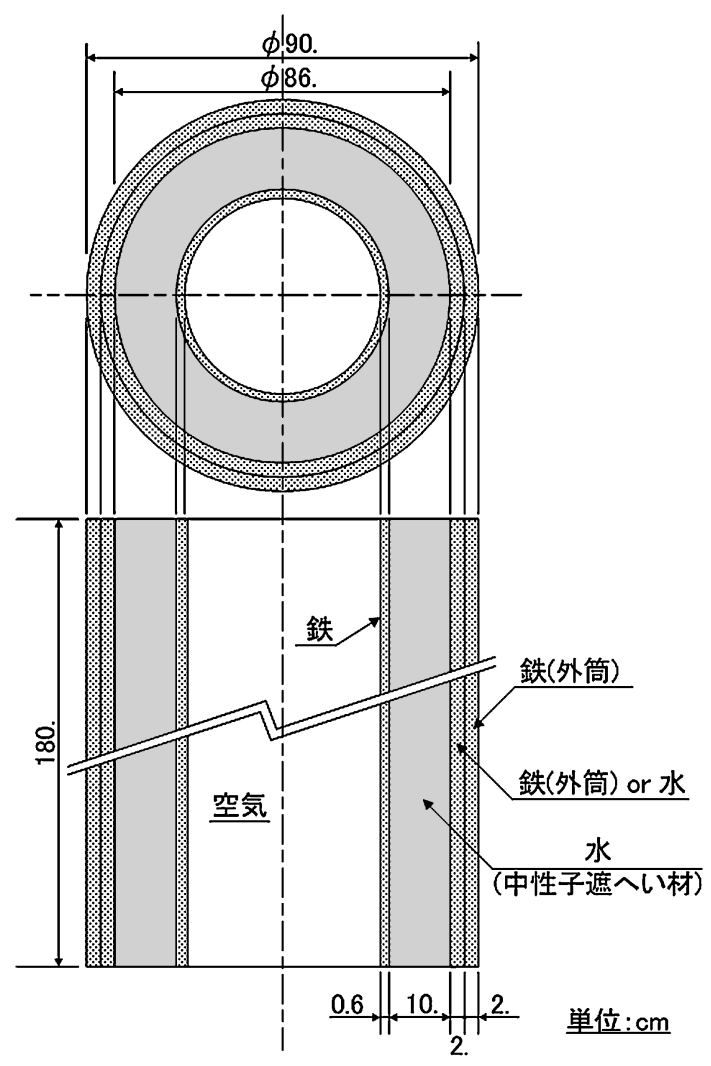

第 7 図 模擬キャスク計算モデル
$4 \mathrm{~cm}$, 配列間隔は $140 \mathrm{~cm}$ (基本ケース) と $110 \mathrm{~cm}$ である。 (2) 解析結果

（a）模擬キャスクなしの場合の中性子線量率分布 相互遮へい効果実験計算ケースを第 2 表に示す。模擬 キャスクを配置しないケースでは, 線源部近傍と模擬キャ スク配列時の外縁部における中性子線量率を測定した。線 源部近傍の測定方向は, A-ライン (実験孔出口から前方方 向), B-ライン(実験孔出口から $90^{\circ}$ 方向) および $\mathrm{C}$-ライン

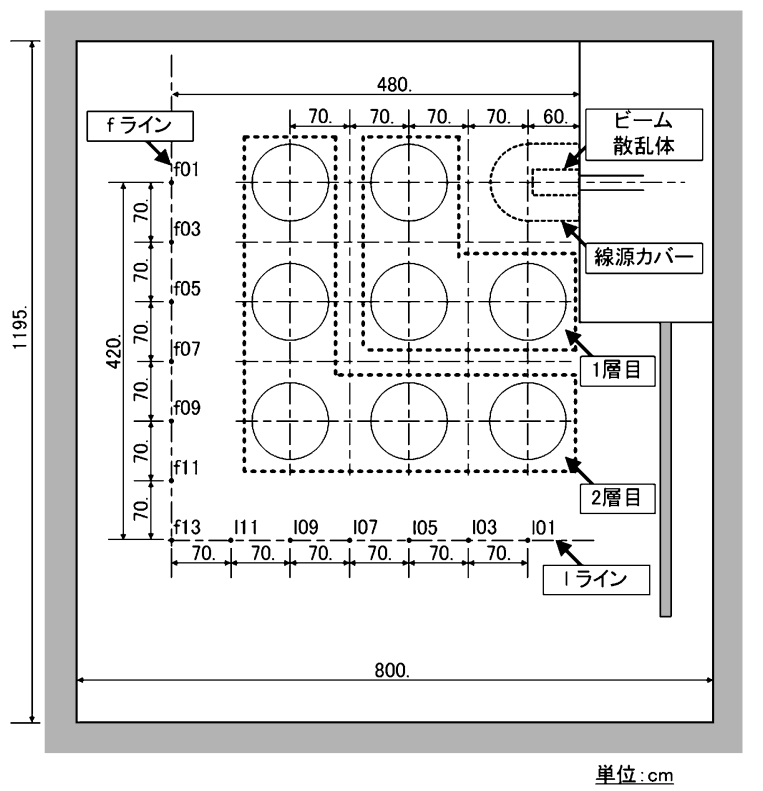

第 8 図 相互遮へい効果計算モデル(平面図)

第 2 表 相互遮へい効果実験計算ケース

\begin{tabular}{cccc}
\hline $\begin{array}{c}\text { 計算ケース } \\
\text { ID }\end{array}$ & キャスク配列 & $\begin{array}{c}\text { 鉄の厚さ } \\
(\mathrm{cm})\end{array}$ & $\begin{array}{c}\text { キャスク中心 } \\
\text { 間距離 }(\mathrm{cm})\end{array}$ \\
\hline 000 & キャスクなし & - & - \\
120 & 1 層 & 2 & 140 \\
220 & 2 層 & 2 & 140 \\
240 & 2 層 & 4 & 140 \\
221 & 2 層 & 2 & 110 \\
\hline
\end{tabular}

第 1 表＼cjkstart計算に使用した原子個数密度

単位 : 個 $/ \mathrm{cm}^{3}$

\begin{tabular}{|c|c|c|c|c|c|c|}
\hline 元 素 & 空 気 & $\begin{array}{c}\text { 鉄 } \\
\text { (ビーム散乱体) }\end{array}$ & $($ キャスク鉄 & ポリエチレン & 水 & 鉛 \\
\hline $\mathrm{H}$ & $7.20 \mathrm{E}+15^{\mathrm{a})}$ & - & - & $7.88 \mathrm{E}+22$ & $6.61 \mathrm{E}+22$ & - \\
\hline $\mathrm{C}$ & $7.58 \mathrm{E}+15$ & - & - & $3.95 \mathrm{E}+22$ & - & - \\
\hline $\mathrm{N}$ & $3.91 \mathrm{E}+19$ & - & - & - & - & - \\
\hline $\mathrm{O}$ & $1.05 \mathrm{E}+19$ & - & - & - & $3.30 \mathrm{E}+22$ & - \\
\hline $\mathrm{Fe}$ & - & $8.38 \mathrm{E}+22$ & $8.49 \mathrm{E}+22$ & - & - & - \\
\hline $\mathrm{Pb}$ & - & - & - & - & - & $3.30 \mathrm{E}+22$ \\
\hline 密度 $\left(\mathrm{g} / \mathrm{cm}^{3}\right)$ & $1.19 \mathrm{E}-03$ & 7.774 & 7.87 & 0.918 & 0.988 & 11.35 \\
\hline
\end{tabular}

a) $7.20 \mathrm{E}+15=7.20 \times 10^{15}$ 
(実験孔出口から $45^{\circ}$ 方向)の 3 方向である(第 9 図)。外縁 部の測定位置は，第 8 図のf-ラインと1-ラインである。 線源部近傍の 3 方向の中性子線量率を第10図に示す。外 緑部に抢ける中性子線量率を第11図に, 計算值 $(\mathrm{C})$ と測定 值 $(\mathrm{E})$ の比率 (以下，「C/E」という。)を第 3 表に示す。計 算值は $20 \%$ 以内で測定値と一致しており, 中性子線量率 分布をよく再現している。

（b）模擬キャスクを配列した場合の中性子線量率分布

模擬キャスクを配列した場合の外緑部( $\mathrm{f}-$ ラインと 1-ラ

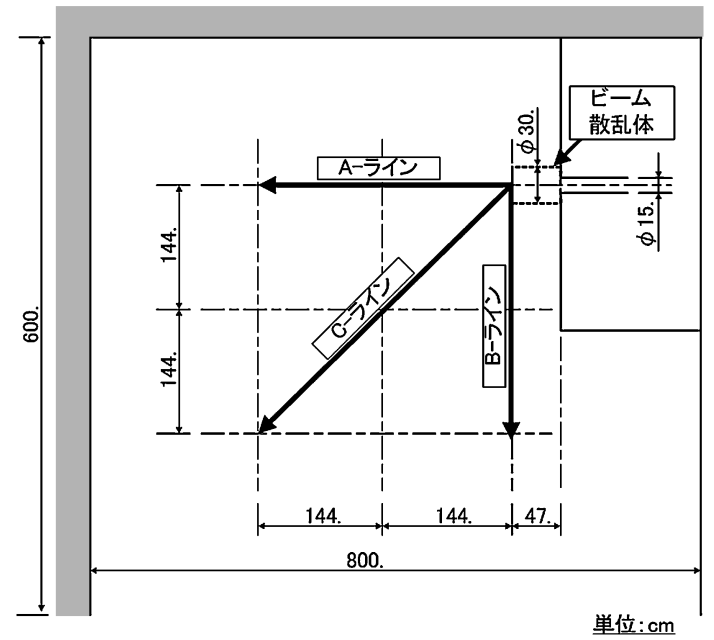

第 9 図 3 方向計算モデル (平面図) (模擬キャスクがない場合)

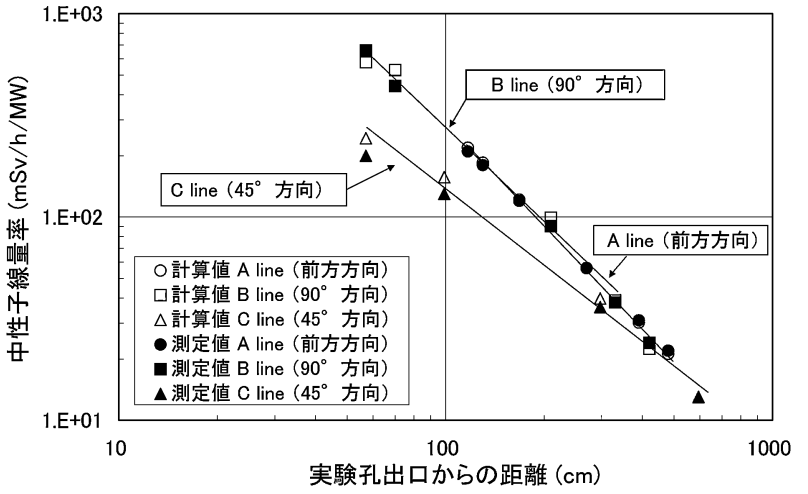

第10図 3 方向の中性子線量率分布 (模擬キャスクがない場合の 線源部近傍)

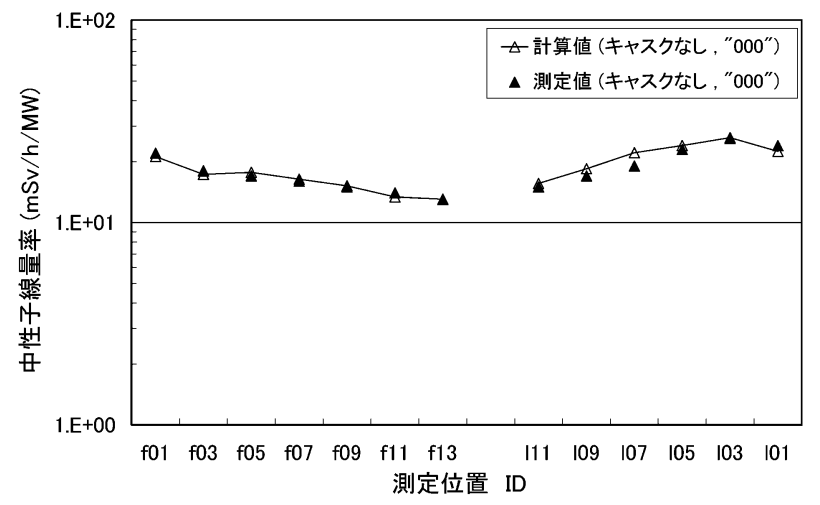

第11図 中性子線量率分布(模擬キャスクがない場合の外縁部)

第 3 表 模擬キャスク配列の違いによる中性子線量率

\begin{tabular}{|c|c|c|c|c|c|c|c|c|}
\hline \multirow{2}{*}{$\begin{array}{c}\text { キャスク } \\
\text { 配列 }\end{array}$} & \multirow{2}{*}{$\begin{array}{l}\text { 測定値 } \\
\text { ID }\end{array}$} & \multicolumn{3}{|c|}{ 中性子線量率 (mSv/h/MW) } & \multirow{2}{*}{$\begin{array}{l}\text { 測定値 } \\
\text { ID }\end{array}$} & \multicolumn{3}{|c|}{ 中性子線量率 (mSv/h/MW) } \\
\hline & & $\begin{array}{c}\text { 測定値 } \\
(\mathrm{E})\end{array}$ & $\begin{array}{c}\text { 計算値 } \\
(\mathrm{C})\end{array}$ & $(\mathrm{C} / \mathrm{E})$ & & $\begin{array}{c}\text { 測定値 } \\
(\mathrm{E})\end{array}$ & $\begin{array}{c}\text { 計算值 } \\
(\mathrm{C})\end{array}$ & $(\mathrm{C} / \mathrm{E})$ \\
\hline \multirow{7}{*}{$\begin{array}{l}\text { なし } \\
(000)\end{array}$} & f01 & $2.2 \mathrm{E}+01$ & $2.1 \mathrm{E}+01$ & 0.96 & 101 & $2.4 \mathrm{E}+01$ & $2.2 \mathrm{E}+01$ & 0.94 \\
\hline & f03 & $1.8 \mathrm{E}+01$ & $1.7 \mathrm{E}+01$ & 0.96 & 103 & $2.6 \mathrm{E}+01$ & $2.6 \mathrm{E}+01$ & 1.01 \\
\hline & f05 & $1.7 \mathrm{E}+01$ & $1.8 \mathrm{E}+01$ & 1.04 & 105 & $2.3 \mathrm{E}+01$ & $2.4 \mathrm{E}+01$ & 1.04 \\
\hline & f07 & $1.6 \mathrm{E}+01$ & $1.6 \mathrm{E}+01$ & 1.02 & 107 & $1.9 \mathrm{E}+01$ & $2.2 \mathrm{E}+01$ & 1.16 \\
\hline & f09 & $1.5 \mathrm{E}+01$ & $1.5 \mathrm{E}+01$ & 1.01 & 109 & $1.7 \mathrm{E}+01$ & $1.8 \mathrm{E}+01$ & 1.08 \\
\hline & f11 & $1.4 \mathrm{E}+01$ & $1.3 \mathrm{E}+01$ & 0.96 & 111 & $1.5 \mathrm{E}+01$ & $1.6 \mathrm{E}+01$ & 1.04 \\
\hline & $\mathrm{f} 13$ & $1.3 \mathrm{E}+01$ & $1.3 \mathrm{E}+01$ & 1.00 & & & & \\
\hline \multirow{7}{*}{$\begin{array}{c}1 \text { 層 } \\
(120)\end{array}$} & f01 & $7.8 \mathrm{E}+00$ & $7.3 \mathrm{E}+00$ & 0.94 & 101 & $4.1 \mathrm{E}+00$ & $4.1 \mathrm{E}+00$ & 1.00 \\
\hline & f03 & $8.3 \mathrm{E}+00$ & $7.7 \mathrm{E}+00$ & 0.93 & 103 & $3.7 \mathrm{E}+00$ & $4.0 \mathrm{E}+00$ & 1.09 \\
\hline & f05 & $9.9 \mathrm{E}+00$ & $1.0 \mathrm{E}+01$ & 1.06 & 105 & $4.8 \mathrm{E}+00$ & $4.7 \mathrm{E}+00$ & 0.97 \\
\hline & $\mathrm{f} 07$ & $7.3 \mathrm{E}+00$ & $7.5 \mathrm{E}+00$ & 1.02 & 107 & $4.8 \mathrm{E}+00$ & $5.5 \mathrm{E}+00$ & 1.14 \\
\hline & f09 & $5.2 \mathrm{E}+00$ & $4.4 \mathrm{E}+00$ & 0.84 & 109 & $4.8 \mathrm{E}+00$ & $5.4 \mathrm{E}+00$ & 1.12 \\
\hline & f11 & $3.5 \mathrm{E}+00$ & $2.8 \mathrm{E}+00$ & 0.81 & 111 & $4.6 \mathrm{E}+00$ & $5.7 \mathrm{E}+00$ & 1.25 \\
\hline & $\mathrm{f} 13$ & $3.1 \mathrm{E}+00$ & $2.4 \mathrm{E}+00$ & 0.76 & & & & \\
\hline \multirow{7}{*}{$\begin{array}{l}2 \text { 層 } \\
(220)\end{array}$} & f01 & $5.7 \mathrm{E}+00$ & $4.8 \mathrm{E}+00$ & 0.84 & 101 & $1.5 \mathrm{E}+00$ & $1.4 \mathrm{E}+00$ & 0.93 \\
\hline & f03 & $5.5 \mathrm{E}+00$ & $5.5 \mathrm{E}+00$ & 1.00 & 103 & $2.8 \mathrm{E}+00$ & $2.9 \mathrm{E}+00$ & 1.04 \\
\hline & f05 & $2.8 \mathrm{E}+00$ & $2.4 \mathrm{E}+00$ & 0.86 & 105 & $1.5 \mathrm{E}+00$ & $1.3 \mathrm{E}+00$ & 0.85 \\
\hline & $\mathrm{f} 07$ & $2.7 \mathrm{E}+00$ & $2.1 \mathrm{E}+00$ & 0.79 & 107 & $1.6 \mathrm{E}+00$ & $1.5 \mathrm{E}+00$ & 0.94 \\
\hline & f09 & $2.2 \mathrm{E}+00$ & $1.7 \mathrm{E}+00$ & 0.75 & 109 & $1.4 \mathrm{E}+00$ & $1.2 \mathrm{E}+00$ & 0.85 \\
\hline & f11 & $2.0 \mathrm{E}+00$ & $1.5 \mathrm{E}+00$ & 0.77 & 111 & $3.4 \mathrm{E}+00$ & $3.7 \mathrm{E}+00$ & 1.09 \\
\hline & $\mathrm{f} 13$ & $1.5 \mathrm{E}+00$ & $1.3 \mathrm{E}+00$ & 0.86 & & & & \\
\hline
\end{tabular}


イン)に拈ける中性子線量率とその $\mathrm{C} / \mathrm{E}$ を, 配列のパラ メータごとに示す。模擬キャスク配列数を変化させた場合 の中性子線量率と $\mathrm{C} / \mathrm{E}$ を第12図括よび第 3 表に，模擬キ ヤスク外筒厚さが $4 \mathrm{~cm}$ のときの結果を第 13 図抢よび第 4 表に，模擬キャスクの配列間隔が $110 \mathrm{~cm}$ のときの結果を 第 14 図抢よび第 5 表に示す。外縁部の計算值は，キャス ク中心間距離 $110 \mathrm{~cm}$ の $\mathrm{f} 13,111$ 以外の測定值と, 約 $30 \%$ 以内で一致した。模擬キャスク 2 層目配列計算時におい

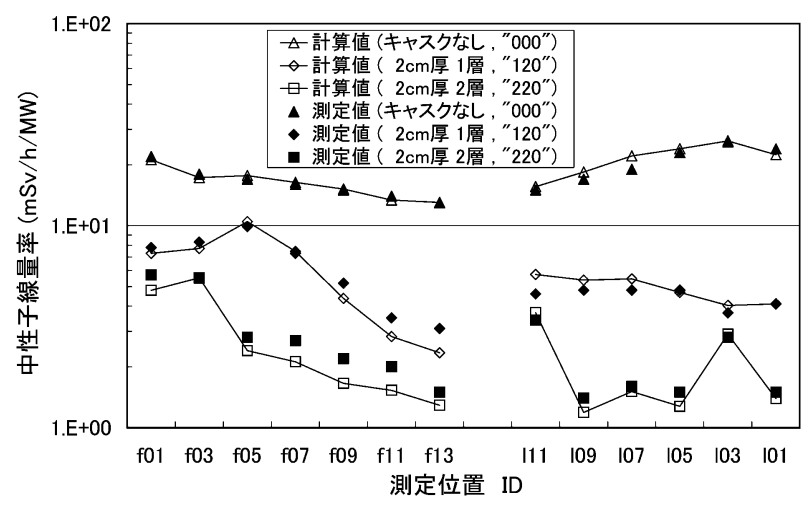

第12図模擬キャスク配列の違いによる中性子線量率分布 (外縁 部)

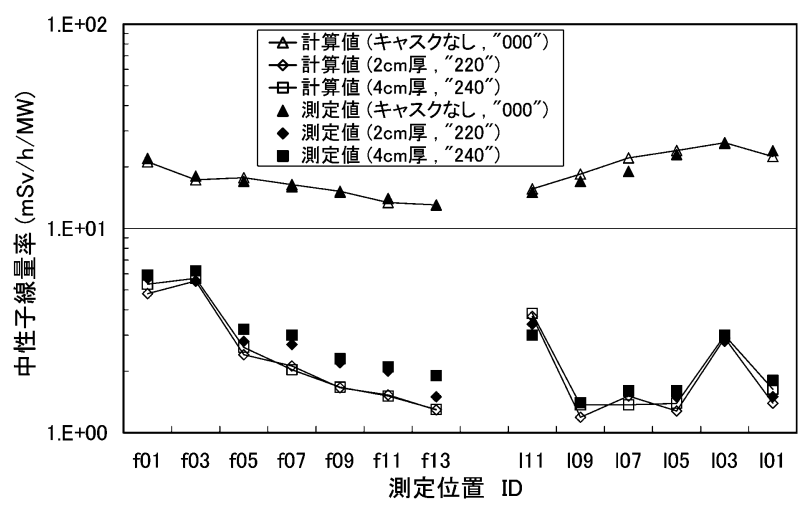

第13図模擬キャスク外筒厚さの違いによる中性子線量率分布 (外縁部)
て，2 層目のキャスク遮へい効果が他の測定点と比較して も特に小さい測定点 $\mathrm{f} 01, \mathrm{f} 03,103,111$ は，今後の検討では 評価対象から除外 (以下，「除外点」という。)する。

(c) 相互遮へい効果による中性子線量減衰率

外縁部(f-ラインと1-ライン)における相互遮へい効果に よる減衰率を，「キャスク 1 層/なし」については第15図 (a)に,「キャスク 2 層/1 層」については第15図(b)に示す。 除外点を除いた評価位置における中性子線量平均減衰率を 第 6 表に示す。計算值と測定值は $10 \%$ 以内で一致した。

(d) 模擬キャスク外筒厚さの効果

外縁部(f-ラインと1-ライン)に抢ける，模擬キャスク外 筒厚さの効果 (厚さ $4 \mathrm{~cm} / 2 \mathrm{~cm}$ ) を第16図に, 線量率の比 を第 7 表に示す。レムカウンタによる中性子線量率の測 定結果は，外筒鉄の厚さを $2 \mathrm{~cm}$ から $4 \mathrm{~cm}$ に増加したこ とにより, 平均して $10 \%$ 程度増加する傾向がみられる。 計算結果は, 平均して $5 \%$ 程度の増加で, 測定結果に比べ て厚さの効果の表れはわずかに小さい。計算誤差が約 10 $\%$, 測定誤差が約 5〜 15\%であるため, 厚さの効果の再現 性について結論を出すことは難しいと考える。ただし，厚 さの違いによる測定值の比 (A) と計算值の比 (B)の比率 $(\mathrm{B} / \mathrm{A})$ が約 $15 \%$ 以内であることから, 計算結果は妥当で

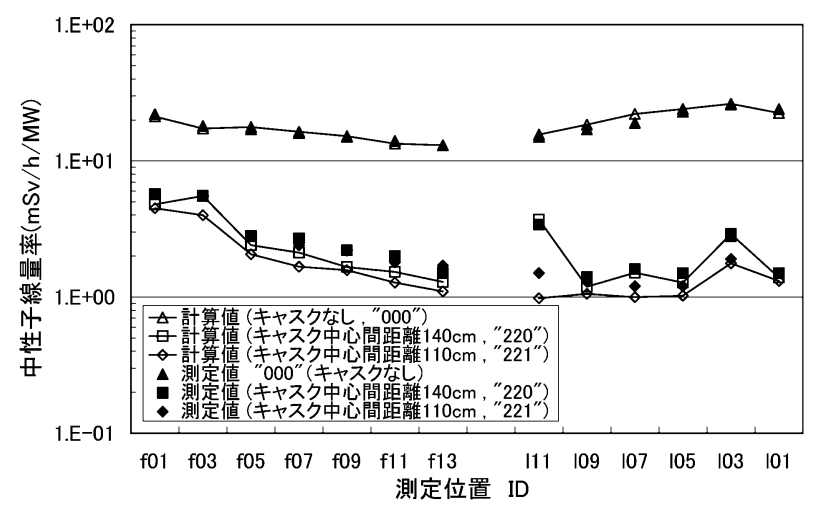

第14図 模擬キャスク配列間隔の違いによる中性子線量率分布 (外縁部)

第 4 表 模擬キャスク外筒厚さが $4 \mathrm{~cm}$ のときの中性子線量率

\begin{tabular}{|c|c|c|c|c|c|c|c|c|}
\hline \multirow{2}{*}{$\begin{array}{c}\text { キャスク } \\
\text { 配列 }\end{array}$} & \multirow{2}{*}{$\begin{array}{l}\text { 測定值 } \\
\text { ID }\end{array}$} & \multicolumn{3}{|c|}{ 中性子線量率 (mSv/h/MW) } & \multirow{2}{*}{$\begin{array}{l}\text { 測定值 } \\
\text { ID }\end{array}$} & \multicolumn{3}{|c|}{ 中性子線量率 (mSv/h/MW) } \\
\hline & & $\begin{array}{c}\text { 測定值 } \\
(\mathrm{E})\end{array}$ & $\begin{array}{c}\text { 計算值 } \\
(\mathrm{C})\end{array}$ & $(\mathrm{C} / \mathrm{E})$ & & $\begin{array}{c}\text { 測定值 } \\
(\mathrm{E})\end{array}$ & $\begin{array}{c}\text { 計算值 } \\
(\mathrm{C})\end{array}$ & $(\mathrm{C} / \mathrm{E})$ \\
\hline \multirow{7}{*}{$\begin{array}{l}2 \text { 層 } \\
(240)\end{array}$} & f01 & $5.9 \mathrm{E}+00$ & $5.3 \mathrm{E}+00$ & $(0.90)$ & 101 & $1.8 \mathrm{E}+00$ & $1.6 \mathrm{E}+00$ & 0.91 \\
\hline & f03 & $6.2 \mathrm{E}+00$ & $5.7 \mathrm{E}+00$ & $(0.92)$ & 103 & $3.0 \mathrm{E}+00$ & $3.0 \mathrm{E}+00$ & $(1.00)$ \\
\hline & f05 & $3.2 \mathrm{E}+00$ & $2.6 \mathrm{E}+00$ & 0.82 & 105 & $1.6 \mathrm{E}+00$ & $1.4 \mathrm{E}+00$ & 0.87 \\
\hline & $\mathrm{f} 07$ & $3.0 \mathrm{E}+00$ & $2.0 \mathrm{E}+00$ & 0.68 & 107 & $1.6 \mathrm{E}+00$ & $1.4 \mathrm{E}+00$ & 0.86 \\
\hline & f09 & $2.3 \mathrm{E}+00$ & $1.7 \mathrm{E}+00$ & 0.73 & 109 & $1.4 \mathrm{E}+00$ & $1.4 \mathrm{E}+00$ & 0.98 \\
\hline & $\mathrm{f} 11$ & $2.1 \mathrm{E}+00$ & $1.5 \mathrm{E}+00$ & 0.72 & 111 & $3.0 \mathrm{E}+00$ & $3.8 \mathrm{E}+00$ & $(1.28)$ \\
\hline & f13 & $1.9 \mathrm{E}+00$ & $1.3 \mathrm{E}+00$ & 0.68 & & & & \\
\hline
\end{tabular}

除外するデータの $\mathrm{C} / \mathrm{E}$ は ( )で示す。 


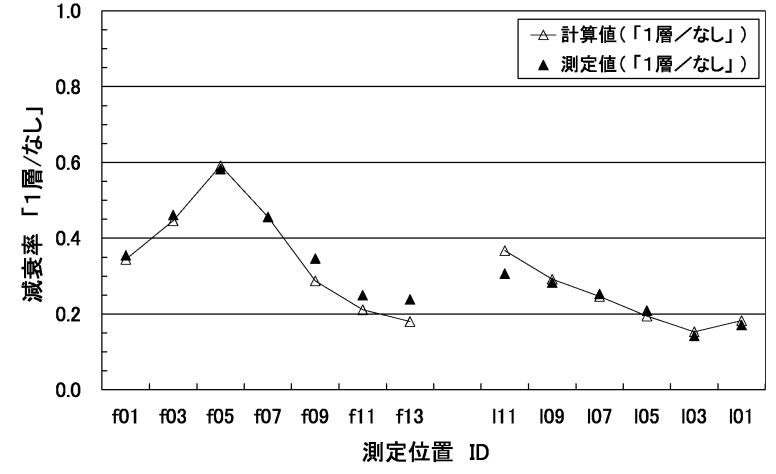

(a)「キャスク 1 層/なし」

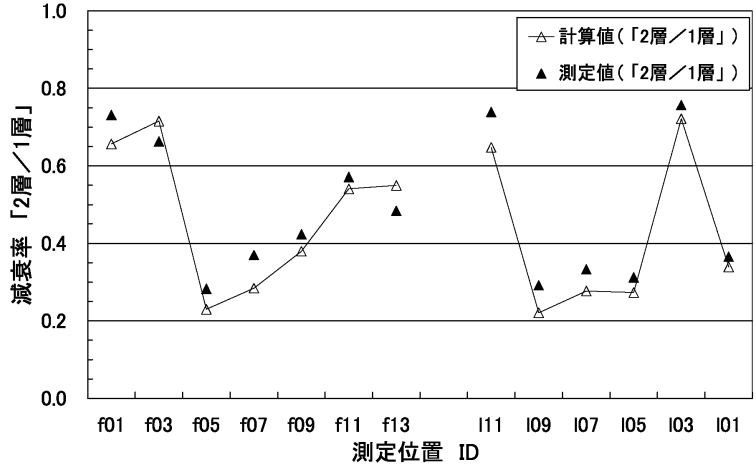

（b）「キャスク 2 層 $/ 1$ 層」

第15図 相互遮へい効果による中性子線量減衰率

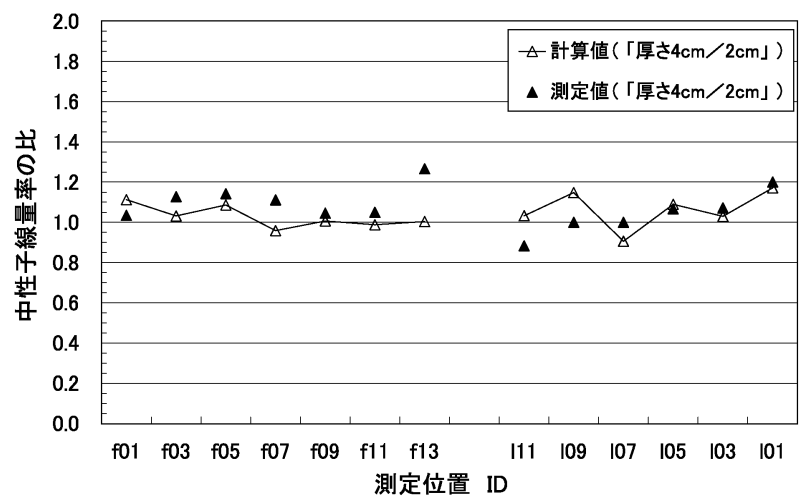

第16図＼cjkstart模擬キャスク外筒厚さの効果(厚さ $4 \mathrm{~cm} / 2 \mathrm{~cm}$ )

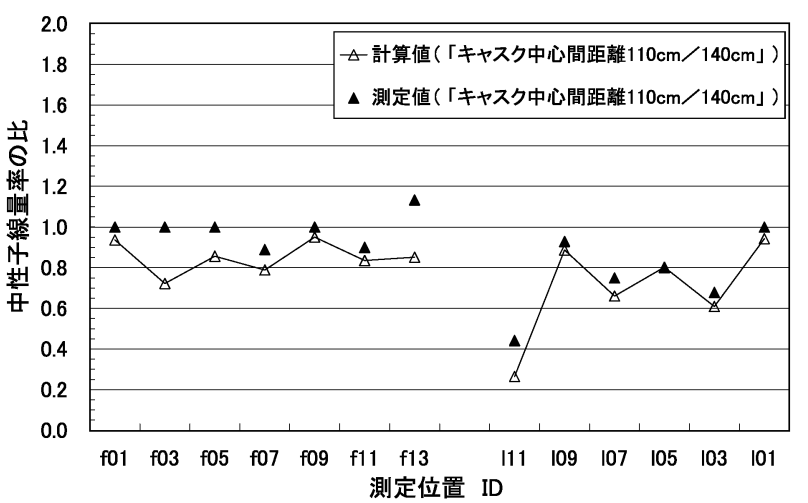

第17図 模擬キャスク配列間隔の効果 (キャスク中心間距離 110 $\mathrm{cm} / 140 \mathrm{~cm}$ )

第 5 表 模擬キャスク配列間隔が $110 \mathrm{~cm}$ のときの中性子線量率

\begin{tabular}{|c|c|c|c|c|c|c|c|c|}
\hline \multirow{2}{*}{$\begin{array}{c}\text { キャスク } \\
\text { 配列 }\end{array}$} & \multirow{2}{*}{$\begin{array}{l}\text { 測定値 } \\
\text { ID }\end{array}$} & \multicolumn{3}{|c|}{ 中性子線量率 (mSv/h/MW) } & \multirow{2}{*}{$\begin{array}{l}\text { 測定值 } \\
\text { ID }\end{array}$} & \multicolumn{3}{|c|}{ 中性子線量率 $(\mathrm{mSv} / \mathrm{h} / \mathrm{MW})$} \\
\hline & & 測定值 & 計算値 & $\mathrm{C} / \mathrm{E}$ & & 測定值 & 計算値 & $\mathrm{C} / \mathrm{E}$ \\
\hline \multirow{7}{*}{$\begin{array}{l}2 \text { 層 } \\
(221)\end{array}$} & f01 & $5.7 \mathrm{E}+00$ & $4.5 \mathrm{E}+00$ & $(0.79)$ & 101 & $1.5 \mathrm{E}+00$ & $1.3 \mathrm{E}+00$ & 0.88 \\
\hline & f03 & $5.5 \mathrm{E}+00$ & $4.0 \mathrm{E}+00$ & $(0.73)$ & 103 & $1.9 \mathrm{E}+00$ & $1.8 \mathrm{E}+00$ & $(0.93)$ \\
\hline & $\mathrm{f} 05$ & $2.8 \mathrm{E}+00$ & $2.1 \mathrm{E}+00$ & 0.74 & 105 & $1.2 \mathrm{E}+00$ & $1.0 \mathrm{E}+00$ & 0.85 \\
\hline & f07 & $2.4 \mathrm{E}+00$ & $1.7 \mathrm{E}+00$ & 0.70 & 107 & $1.2 \mathrm{E}+00$ & $1.0 \mathrm{E}+00$ & 0.83 \\
\hline & f09 & $2.2 \mathrm{E}+00$ & $1.6 \mathrm{E}+00$ & 0.72 & 109 & $1.3 \mathrm{E}+00$ & $1.1 \mathrm{E}+00$ & 0.81 \\
\hline & $\mathrm{f} 11$ & $1.8 \mathrm{E}+00$ & $1.3 \mathrm{E}+00$ & 0.71 & 111 & $1.5 \mathrm{E}+00$ & $9.8 \mathrm{E}-01$ & $(0.65)$ \\
\hline & $\mathrm{f} 13$ & $1.7 \mathrm{E}+00$ & $1.1 \mathrm{E}+00$ & 0.65 & & & & \\
\hline
\end{tabular}

除外するデータの $\mathrm{C} / \mathrm{E}$ は（ ）で示す。

第 6 表 相互遮へい効果による中性子線量の平均減衰率

\begin{tabular}{lccc}
\hline & $\begin{array}{c}\text { 測定值 } \\
(\mathrm{E})\end{array}$ & $\begin{array}{c}\text { 計算值 } \\
(\mathrm{C})\end{array}$ & $(\mathrm{C} / \mathrm{E})$ \\
\hline 1 層/なし & 0.31 & 0.29 & 0.95 \\
2 層/1 層 & 0.38 & 0.34 & 0.90 \\
\hline
\end{tabular}

ある。

(e) 模擬キャスク配列間隔の効果

外縁部( $\mathrm{f}$-ラインと1-ライン)に抢ける, 模擬キャスク配 列間隔の効果 (キャスク間隔 $110 \mathrm{~cm} / 140 \mathrm{~cm}$ ) を第 $\mathbf{1 7}$ 図
に, 線量率の比を第 8 表に示す。キャスク配列間隔の 140 $\mathrm{cm}$ から $110 \mathrm{~cm}$ への変化に対して, 中性子線量率が $20 \%$ 以上減少している1ラインの測定点は 103, 105, 107, 111 で ある。111を除いて, 計算結果は, この配列間隔の効果を 約 $10 \%$ 以内の精度で再現した。

\section{3.ダクトストリーミング実験}

\section{(1) 解析条件}

ダクト内やコンクリート製ルーバーの枚数を変化させ, ルーバー前後における各測定点でのレムカウンタによる中 性子線量率の測定值と計算值を比較した。 
第 7 表 模擬キャスク外筒厚さに対する線量率の比(厚さ $4 \mathrm{~cm} / 2 \mathrm{~cm}$ )

\begin{tabular}{|c|c|c|c|c|c|c|c|}
\hline \multirow{2}{*}{$\begin{array}{l}\text { 測定点 } \\
\text { ID }\end{array}$} & \multicolumn{3}{|c|}{ 中性子線量率(mSv/h/MW) } & \multirow{2}{*}{$\begin{array}{c}\text { 測定点 } \\
\text { ID }\end{array}$} & \multicolumn{3}{|c|}{ 中性子線量率 (mSv/h/MW) } \\
\hline & $\begin{array}{c}\text { 測定值の比 } \\
\text { (A) }\end{array}$ & $\begin{array}{c}\text { 計算值の比 } \\
(\mathrm{B})\end{array}$ & (B) / (A) & & $\begin{array}{c}\text { 測定值の比 } \\
\text { (A) }\end{array}$ & $\begin{array}{l}\text { 計算值の比 } \\
\text { (B) }\end{array}$ & (B) $/(\mathrm{A})$ \\
\hline f01 & 1.04 & 1.11 & $(1.07)$ & 101 & 1.20 & 1.17 & 0.98 \\
\hline $\mathrm{f} 03$ & 1.13 & 1.03 & $(0.92)$ & 103 & 1.07 & 1.03 & $(0.96)$ \\
\hline $\mathrm{f} 05$ & 1.14 & 1.09 & 0.95 & 105 & 1.07 & 1.09 & 1.02 \\
\hline $\mathrm{f} 07$ & 1.11 & 0.96 & 0.86 & 107 & 1.00 & 0.91 & 0.91 \\
\hline f09 & 1.05 & 1.01 & 0.96 & 109 & 1.00 & 1.15 & 1.15 \\
\hline $\mathrm{f} 11$ & 1.05 & 0.99 & 0.94 & 111 & 0.88 & 1.03 & $(1.17)$ \\
\hline $\mathrm{f} 13$ & 1.27 & 1.00 & 0.79 & & & & \\
\hline
\end{tabular}

除外するデータの $(\mathrm{B}) /(\mathrm{A})$ は ( )で示す。

第 8 表 模擬キャスク中心間距離に対する線量率の比 $(110 \mathrm{~cm} / 140 \mathrm{~cm})$

\begin{tabular}{|c|c|c|c|c|c|c|c|}
\hline \multirow{2}{*}{$\begin{array}{l}\text { 測定点 } \\
\text { ID }\end{array}$} & \multicolumn{3}{|c|}{ 中性子線量率 (mSv/h/MW) } & \multirow{2}{*}{$\begin{array}{c}\text { 測定点 } \\
\text { ID }\end{array}$} & \multicolumn{3}{|c|}{ 中性子線量率 (mSv/h/MW) } \\
\hline & $\begin{array}{c}\text { 測定值の比 } \\
(\mathrm{A})\end{array}$ & $\begin{array}{c}\text { 計算值の比 } \\
(\mathrm{B})\end{array}$ & (B) $/(\mathrm{A})$ & & $\begin{array}{c}\text { 測定值の比 } \\
(\mathrm{A})\end{array}$ & $\begin{array}{c}\text { 計算值の比 } \\
(\mathrm{B})\end{array}$ & (B) $/(\mathrm{A})$ \\
\hline $\mathrm{f} 01$ & 1.00 & 0.94 & $(0.94)$ & 101 & 1.00 & 0.94 & 0.94 \\
\hline $\mathrm{f} 03$ & 1.00 & 0.72 & $(0.72)$ & 103 & 0.68 & 0.61 & $(0.90)$ \\
\hline $\mathrm{f} 05$ & 1.00 & 0.86 & 0.86 & 105 & 0.80 & 0.80 & 1.00 \\
\hline $\mathrm{f} 07$ & 0.89 & 0.79 & 0.89 & 107 & 0.75 & 0.66 & 0.88 \\
\hline f09 & 1.00 & 0.95 & 0.95 & 109 & 0.93 & 0.89 & 0.96 \\
\hline $\mathrm{f} 11$ & 0.90 & 0.84 & 0.93 & 111 & 0.44 & 0.26 & $(0.60)$ \\
\hline $\mathrm{f} 13$ & 1.13 & 0.85 & 0.75 & & & & \\
\hline
\end{tabular}

除外するデータの $(\mathrm{B}) /(\mathrm{A})$ は ( )で示す。

中間貯蔵施設の給排気口部のダクト形状を模擬するもの として, 1 回 $90^{\circ}$ 屈曲矩形コンクリートダクトを実験孔の 前に設置した。ダクトの内法寸法は, 実験孔の中心軸高さ $87.5 \mathrm{~cm}$ を考慮して高さ $180 \mathrm{~cm}$ ，約 $6 \mathrm{~m}$ 四方以上の実験 施設の広さから幅は $160 \mathrm{~cm}$ とした。ダクト中心軸長さに ついても実験施設の広さを考慮して, 第 1 脚が $470 \mathrm{~cm}$, 第 2 脚が $550 \mathrm{~cm}$ とした。ダクト側壁抢よび天井の厚さ は, 予備解析の結果から, ダクト周端部から放出された中 性子が第 2 脚内のルーバー付近の測定值に対して影響し ないことを考慮し $50 \mathrm{~cm}$ とした。コンクリート製ルー バーは, 1 回屈曲ダクトの 2 脚目位置に設置した。ルー バー板の厚さは施工性と中性子線量低減効果から 10１5 $\mathrm{cm}$ が必要となるが，ダクトの断面寸法を考慮して 12.5 $\mathrm{cm}$ とした。ルーバー板を設置する第 2 脚の長さとルー バー後方の測定点に抢けるダクト開口部等からの散乱放射 線の影響低減を考慮して長さは $195 \mathrm{~cm}$ とした。高さは, ルーバー板をダクトの床から天井に渡って鉛直方向に設置 するために $172 \mathrm{~cm}$ とした。ダクトストリーミング計算モ デルを第18図に示す。ダクト内第 2 脚に打けるレムカウ ンタ測定点を第19図に示す。ダクト壁とルーバーのコン クリート組成は化学分析值を用いた。計算に使用した原子 個数密度を第 9 表に示す。

計算ケースは, ルーバーの設置枚数を「なし $/ 3$ 枚 $/ 4$ 枚」 とした 3 ケースである。
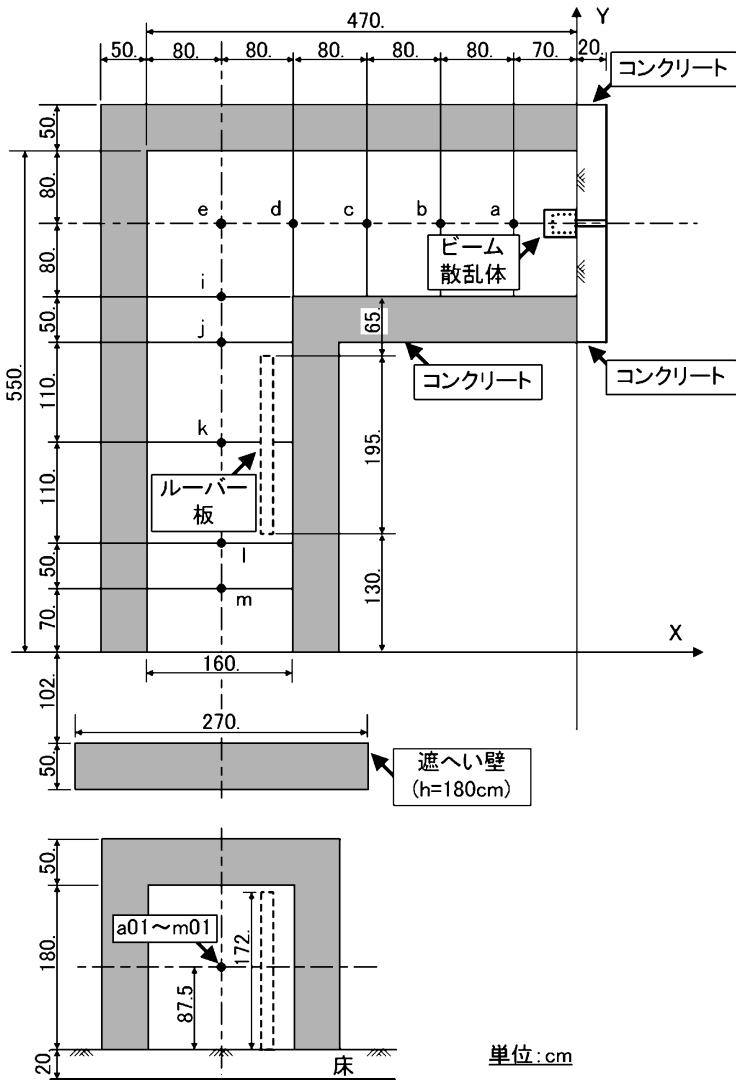

第18図ダクトストリーミング計算モデル 

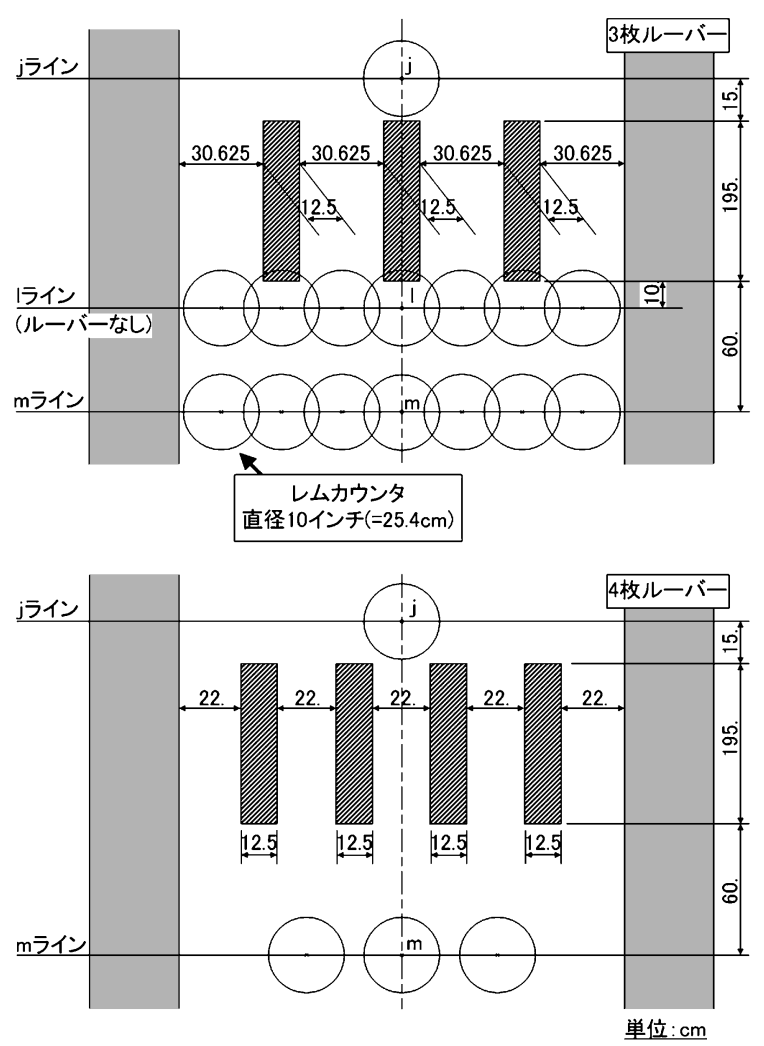

第19図 ダクト内のレムカウンタ測定点

第 9 表 ダクトストリーミング計算に使用したコンクリート の原子個数密度

単位：個 $/ \mathrm{cm}^{3}$

\begin{tabular}{ccccc}
\hline 元 素 & $\begin{array}{c}\text { 第 } 1 \text { 脚の } \\
\text { ダクト側壁 }\end{array}$ & $\begin{array}{c}\text { 第 } 2 \text { 脚の } \\
\text { ダ側壁 }\end{array}$ & $\begin{array}{c}\text { 天井 } \\
\text { ルーバー }\end{array}$ & 床 \\
\hline $\mathrm{H}$ & $1.04 \mathrm{E}+22$ & $1.06 \mathrm{E}+22$ & $9.71 \mathrm{E}+21$ & $9.22 \mathrm{E}+21$ \\
$\mathrm{C}$ & $2.18 \mathrm{E}+21$ & $2.04 \mathrm{E}+21$ & $3.23 \mathrm{E}+21$ & $5.42 \mathrm{E}+20$ \\
$\mathrm{O}$ & $4.44 \mathrm{E}+22$ & $4.60 \mathrm{E}+22$ & $4.27 \mathrm{E}+22$ & $3.90 \mathrm{E}+22$ \\
$\mathrm{Na}$ & $1.19 \mathrm{E}+20$ & $1.69 \mathrm{E}+20$ & $9.33 \mathrm{E}+19$ & $5.05 \mathrm{E}+19$ \\
$\mathrm{Mg}$ & $6.90 \mathrm{E}+20$ & $4.92 \mathrm{E}+20$ & $9.65 \mathrm{E}+20$ & $3.20 \mathrm{E}+20$ \\
$\mathrm{Al}$ & $1.05 \mathrm{E}+21$ & $1.22 \mathrm{E}+21$ & $7.85 \mathrm{E}+20$ & $8.18 \mathrm{E}+20$ \\
$\mathrm{Si}$ & $1.33 \mathrm{E}+22$ & $1.45 \mathrm{E}+22$ & $1.12 \mathrm{E}+22$ & $1.42 \mathrm{E}+22$ \\
$\mathrm{~S}$ & $1.32 \mathrm{E}+20$ & $6.53 \mathrm{E}+19$ & $1.43 \mathrm{E}+20$ & $1.34 \mathrm{E}+20$ \\
$\mathrm{Cl}$ & $7.70 \mathrm{E}+17$ & $7.85 \mathrm{E}+17$ & $7.56 \mathrm{E}+17$ & $6.56 \mathrm{E}+17$ \\
$\mathrm{~K}$ & $2.72 \mathrm{E}+20$ & $3.17 \mathrm{E}+20$ & $2.33 \mathrm{E}+20$ & $1.60 \mathrm{E}+20$ \\
$\mathrm{Ca}$ & $4.91 \mathrm{E}+21$ & $4.21 \mathrm{E}+21$ & $5.69 \mathrm{E}+21$ & $2.46 \mathrm{E}+21$ \\
$\mathrm{Mn}$ & $9.93 \mathrm{E}+18$ & $7.60 \mathrm{E}+18$ & $1.22 \mathrm{E}+19$ & $1.06 \mathrm{E}+19$ \\
$\mathrm{Fe}$ & $3.10 \mathrm{E}+20$ & $2.99 \mathrm{E}+20$ & $3.36 \mathrm{E}+20$ & $2.62 \mathrm{E}+20$ \\
密度 & 2.32 & 2.37 & 2.25 & 1.98 \\
$\left(\mathrm{~g} / \mathrm{cm}^{3}\right)$ & & & & \\
\hline
\end{tabular}

\section{(2) 解析結果}

（a）ダクト軸上の中性子線量率分布

ダクト軸上の中性子線量率を第20図に，その C $/ \mathrm{E}$ を第 10 表に示す。第 1 脚の $\mathrm{C} / \mathrm{E}$ は0.95〜 1.1 , 第 2 脚の $\mathrm{C} / \mathrm{E}$ は0.70〜 1.0 となり, 計算值と測定值は約 $30 \%$ 以内で一致 し，減衰傾向の再現性も良好である。

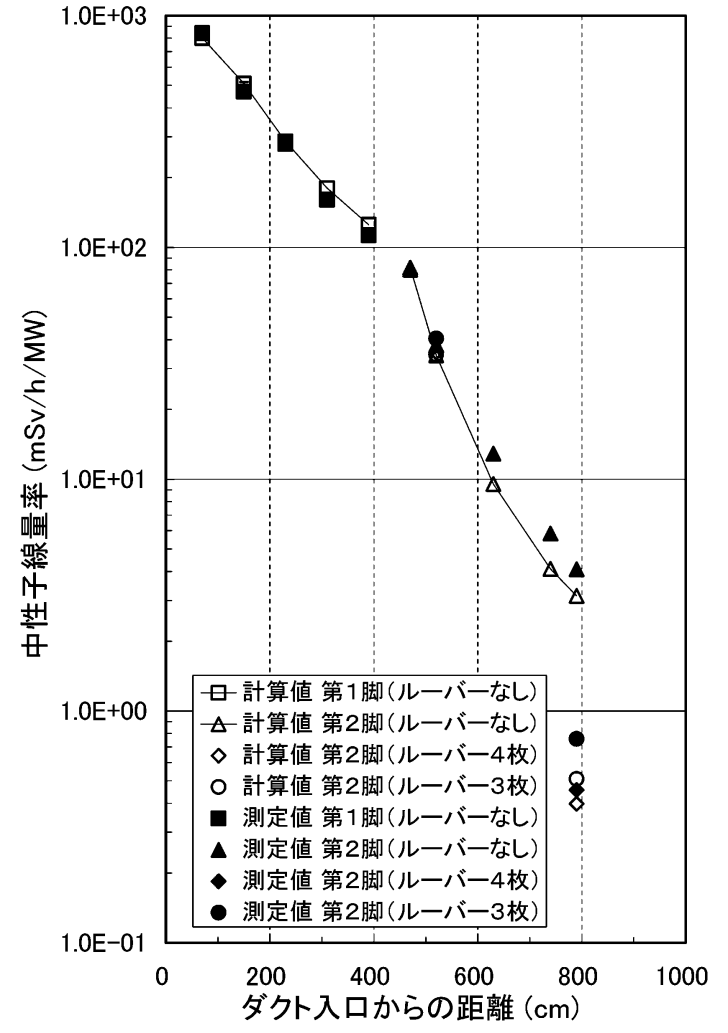

第20図 ダクト軸上の中性子線量率分布

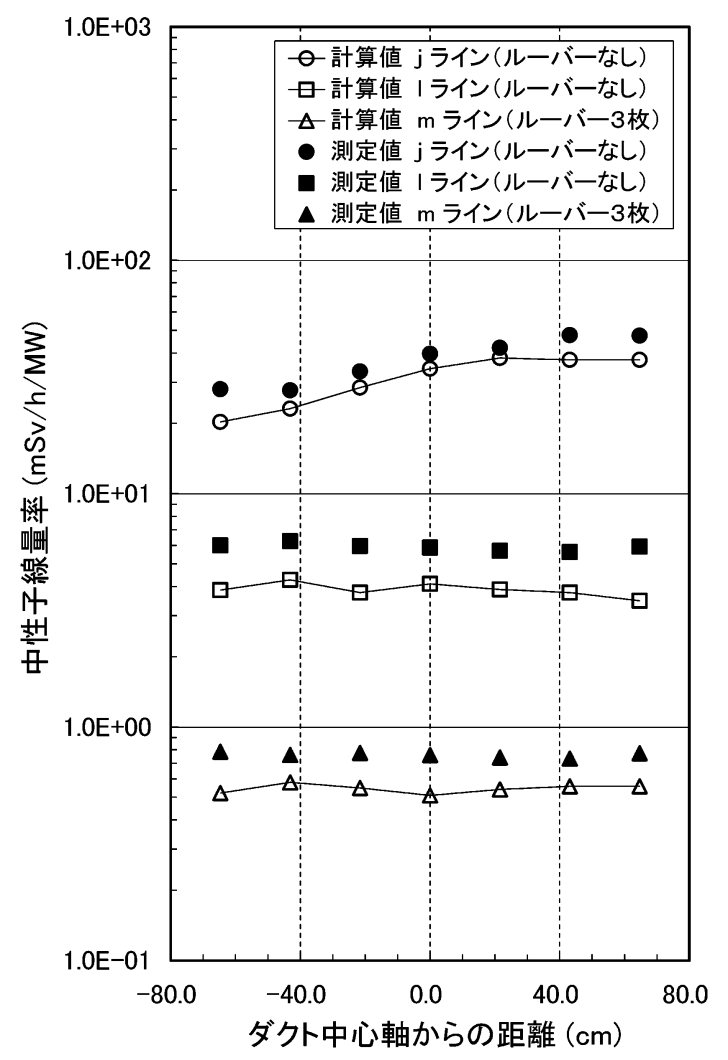

第21図 第 2 脚ダクト断面に扔ける中性子線量率分布

（b）ダクト断面の中性子線量率分布

第 2 脚のダクト断面に打ける中性子線量率を第21図に 示す。ルーバーなし， 3 枚ルーバーの断面分布がよく再現 
第10表 ダクト内(中心軸)の中性子線量率

\begin{tabular}{|c|c|c|c|c|c|c|c|c|c|c|c|}
\hline \multirow{2}{*}{$\begin{array}{l}\text { 測 } \\
\text { 定 } \\
\text { 位 } \\
\text { 㯰 }\end{array}$} & \multirow{2}{*}{$\begin{array}{l}\text { 測 } \\
\text { 定 } \\
\text { 点 } \\
\text { ID }\end{array}$} & \multirow{2}{*}{$\begin{array}{c}\text { 実験 } \\
\text { 他 } \\
5 \text { 離 } \\
\text { (m) }\end{array}$} & \multicolumn{9}{|c|}{ 中性子線量率 (mSv/h/MW) } \\
\hline & & & $\begin{array}{c}\text { 測定値 } \\
(\mathrm{E})\end{array}$ & $\begin{array}{c}\text { 計算値 } \\
\text { (C) }\end{array}$ & $(\mathrm{C} / \mathrm{E})$ & $\frac{\text { 測定値 }}{(\mathrm{E})}$ & $\begin{array}{c}\text { 計算值 } \\
\text { (C) }\end{array}$ & $(\mathrm{C} / \mathrm{E})$ & $\begin{array}{c}\text { 測定値 } \\
(\mathrm{E})\end{array}$ & $\begin{array}{c}\text { 計算値 } \\
\text { (C) }\end{array}$ & $(\mathrm{C} / \mathrm{E})$ \\
\hline \multicolumn{3}{|c|}{ ルーバー枚数 } & \multicolumn{3}{|c|}{ なし } & \multicolumn{3}{|c|}{4 枚 } & \multicolumn{3}{|c|}{3 枚 } \\
\hline \multirow{5}{*}{$\begin{array}{l}\text { 第 } \\
1 \\
\text { 脚 }\end{array}$} & $\mathrm{a}$ & 0.7 & $8.4 \mathrm{E}+02$ & $8.0 \mathrm{E}+02$ & 0.95 & & - & & & - & \\
\hline & $\mathrm{b}$ & 1.5 & $4.7 \mathrm{E}+02$ & $5.1 \mathrm{E}+02$ & 1.08 & & - & & & - & \\
\hline & $\mathrm{c}$ & 2.3 & $2.8 \mathrm{E}+02$ & $2.9 \mathrm{E}+02$ & 1.03 & & - & & & - & \\
\hline & $\mathrm{d}$ & 3.1 & $1.6 \mathrm{E}+02$ & $1.8 \mathrm{E}+02$ & 1.12 & & - & & & - & \\
\hline & e & 3.9 & $1.1 \mathrm{E}+02$ & $1.3 \mathrm{E}+02$ & 1.11 & & - & & & - & \\
\hline \multirow{5}{*}{$\begin{array}{l}\text { 第 } \\
2 \\
\text { 脚 }\end{array}$} & $\mathrm{i}$ & 4.7 & $8.0 \mathrm{E}+01$ & $8.2 \mathrm{E}+01$ & 1.02 & & - & & & - & \\
\hline & $\mathrm{j}$ & 5.2 & $3.8 \mathrm{E}+01$ & $3.4 \mathrm{E}+01$ & 0.90 & $4.0 \mathrm{E}+01$ & $3.5 \mathrm{E}+01$ & 0.87 & $4.1 \mathrm{E}+01$ & $3.5 \mathrm{E}+01$ & 0.85 \\
\hline & $\mathrm{k}$ & 6.3 & $1.3 \mathrm{E}+01$ & $9.5 \mathrm{E}+00$ & 0.74 & & - & & & - & \\
\hline & 1 & 7.4 & $5.8 \mathrm{E}+00$ & $4.1 \mathrm{E}+00$ & 0.70 & & - & & & - & \\
\hline & $\mathrm{m}$ & 7.9 & $4.1 \mathrm{E}+00$ & $3.1 \mathrm{E}+00$ & 0.77 & $4.6 \mathrm{E}-01$ & $4.0 \mathrm{E}-01$ & 0.87 & $7.6 \mathrm{E}-01$ & $5.1 \mathrm{E}-01$ & 0.67 \\
\hline
\end{tabular}

第11表 ルーバー前後位置での中性子線量率

\begin{tabular}{ccc}
\hline 測定位置 & $\begin{array}{c}\text { 測定点 } \mathrm{j} \text { の } \\
\mathrm{C} / \mathrm{E}\end{array}$ & $\begin{array}{c}\text { 測定点 } \mathrm{m} \text { } \\
\mathrm{C} / \mathrm{E}\end{array}$ \\
\hline 第 2 脚ルーバーなし & 0.90 & 0.77 \\
第 2 脚 4 枚ルーバー & 0.87 & $0.79^{\mathrm{a})}$ \\
第 2 脚 3 枚ルーバー & 0.85 & $0.72^{\mathrm{a})}$ \\
\hline
\end{tabular}

a) $\mathrm{m}$ ライン上にある測定点での平均值

\begin{tabular}{|c|c|c|c|c|}
\hline$\frac{\text { 養生処理 }}{\begin{array}{c}\text { 密度 } \\
\left(\mathrm{g} / \mathrm{cm}^{3}\right)\end{array}}$ & 2.13 & 2.12 & 2.20 & 2.18 \\
\hline$\underset{(\%)}{\text { 自由水 }}$ & 0.52 & 0.40 & 3.10 & 2.72 \\
\hline $\begin{array}{c}\text { 総水分量 } \\
(\%))^{2}\end{array}$ & 5.68 & 6.72 & 9.01 & 9.11 \\
\hline $\mathrm{H}$ & $7.99 \mathrm{E}+21$ & $9.40 \mathrm{E}+21$ & $1.27 \mathrm{E}+22$ & $1.28 \mathrm{E}+22$ \\
\hline $\mathrm{C}$ & $2.51 \mathrm{E}+21$ & $2.37 \mathrm{E}+21$ & $2.60 \mathrm{E}+21$ & $2.31 \mathrm{E}+21$ \\
\hline $\mathrm{O}$ & $3.71 \mathrm{E}+22$ & $3.72 \mathrm{E}+22$ & $3.94 \mathrm{E}+22$ & $3.89 \mathrm{E}+22$ \\
\hline $\mathrm{Si}$ & $1.26 \mathrm{E}+22$ & $1.24 \mathrm{E}+22$ & $1.22 \mathrm{E}+22$ & $1.21 \mathrm{E}+22$ \\
\hline $\mathrm{Al}$ & $9.88 \mathrm{E}+20$ & $1.02 \mathrm{E}+21$ & $1.03 \mathrm{E}+21$ & $1.03 \mathrm{E}+21$ \\
\hline $\mathrm{Fe}$ & $2.88 \mathrm{E}+20$ & $2.61 \mathrm{E}+20$ & $2.92 \mathrm{E}+20$ & $3.04 \mathrm{E}+20$ \\
\hline $\mathrm{Ca}$ & $5.39 \mathrm{E}+21$ & $5.39 \mathrm{E}+21$ & $5.59 \mathrm{E}+21$ & $5.61 \mathrm{E}+21$ \\
\hline $\mathrm{Mg}$ & $7.00 \mathrm{E}+20$ & $7.28 \mathrm{E}+20$ & $7.66 \mathrm{E}+20$ & $8.29 \mathrm{E}+20$ \\
\hline $\mathrm{K}$ & $2.74 \mathrm{E}+20$ & $2.29 \mathrm{E}+20$ & $2.59 \mathrm{E}+20$ & $2.44 \mathrm{E}+20$ \\
\hline $\mathrm{Na}$ & $1.81 \mathrm{E}+20$ & $1.56 \mathrm{E}+20$ & $2.07 \mathrm{E}+20$ & $1.57 \mathrm{E}+20$ \\
\hline $\mathrm{Mn}$ & $1.07 \mathrm{E}+19$ & $9.02 \mathrm{E}+18$ & $7.24 \mathrm{E}+18$ & $7.20 \mathrm{E}+18$ \\
\hline $\mathrm{S}$ & $1.61 \mathrm{E}+20$ & $1.44 \mathrm{E}+20$ & $1.41 \mathrm{E}+20$ & $1.50 \mathrm{E}+20$ \\
\hline $\mathrm{Cl}$ & $9.00 \mathrm{E}+18$ & $7.17 \mathrm{E}+18$ & $2.53 \mathrm{E}+18$ & $5.04 \mathrm{E}+18$ \\
\hline 枚数 & 3 & 3 & 3 & 3 \\
\hline
\end{tabular}

されている。ルーバー前後位置での中性子線量率の計算值 と測定值の比率を第11表に示す。ルーバー後方部(測定点 $\mathrm{m})$ では, 4 枚ルーバーの C / E の平均が $0.79,3$ 枚ルー バーの $\mathrm{C} / \mathrm{E}$ の平均が 0.72 となり, 計算值と測定值は約 30
$\%$ 以内で一致した。

\section{4. コンクリート深層透過実験}

\section{(1) 解析条件}

平板供試体を複数枚積層し, コンクリート厚さを変化さ せた場合の各測定点でのレムカウンタによる中性子線量率 の測定値と計算值を比較した。

平板供試体は, 高さ $120 \mathrm{~cm} \times$ 幅 $100 \mathrm{~cm} \times$ 厚さ $20 \mathrm{~cm}$ の通常養生コンクリートおよび加熱炉内で $100^{\circ} \mathrm{C}$ の状態で 10 日間加熱した乾燥養生コンクリートをそれぞれ 6 枚, 合計 12 枚を製作した。平板供試体厚さは, 実験場での取 り扱い等で破損しないような厚さ，かつ中性子の遮へい性 能への影響が大きい水素含有量 (水分含有量)を一定に管理 することが可能な厚さとして決定した。コンクリート深層 透過実験の中性子減衰特性において, 計算結果に大きく影 響するコンクリートの組成については化学分析を行い，そ の結果を計算条件に反映した。計算に使用した平板供試体 の原子個数密度を第12表に示す。乾燥養生コンクリート は, 通常養生コンクリートに比べて自由水が約 $1 / 6$ に減少 している。なお，コンクリート自身の中性子線量減衰特性 を評価するため, 平板供試体中央部の中性子照射範囲には 鉄筋等は使用していない。

計算モデルでは，実験時の平板供試体の配列および実験 現場での線量率を低減させるために周囲に組上げた遮へい 用コンクリートブロックを忠実に再現した。コンクリート 深層透過計算モデルを第22図, 第23図に示す。平板供試 体 (\#3)の横にある側部遮へいブロック（\#4)のコンクリー ト厚さは $100 \mathrm{~cm}$, 天井部遮へいブロック (\#2)の厚さは 80 $\mathrm{cm}$ である。ただし，炉壁側の側部遮へいブロック $(\# 4)$ は 設置が困難なため $50 \mathrm{~cm}$ の遮へいブロックの 1 ブロック のみとなっている。この側部からの放射線の影響を小さく するために前方に遮へいブロック（\#7）を配置した。

計算ケースは, 通常養生および乾燥養生コンクリートの 


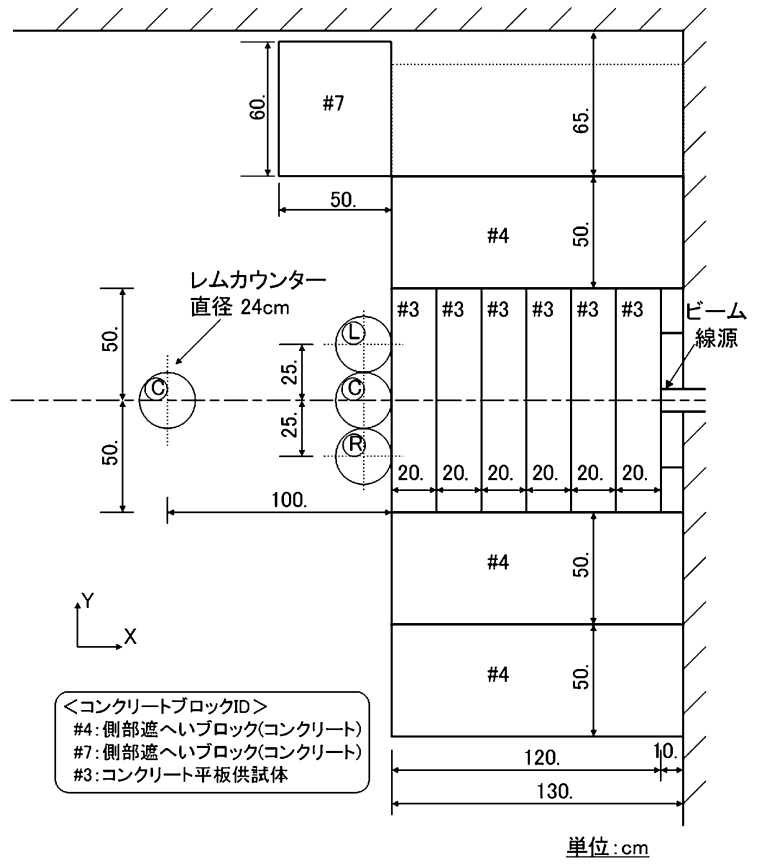

第22図 コンクリート深層透過計算モデル(平面図)

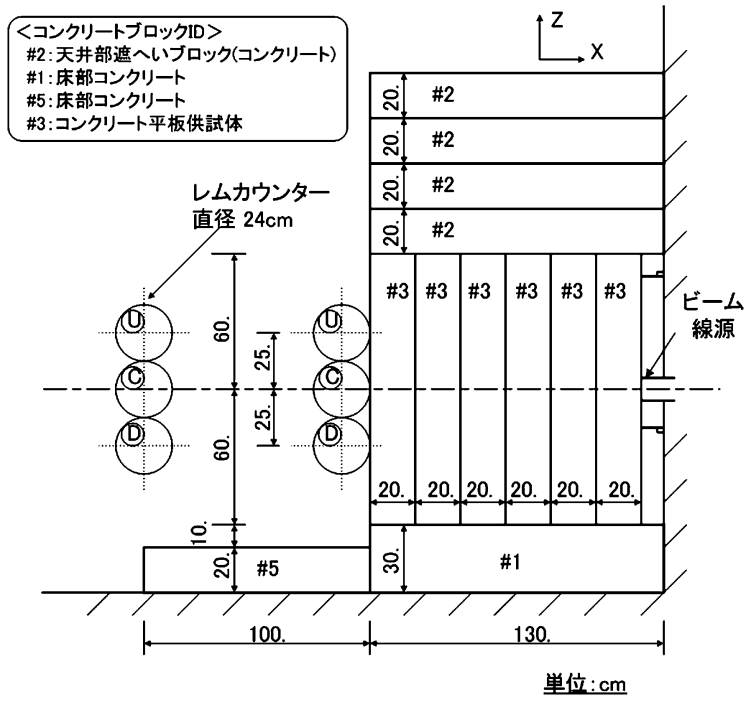

第23図 コンクリート深層透過計算モデル(立面図)
平板供試体の厚さを $40 \mathrm{~cm}$ (2 枚) $120 \mathrm{~cm}$ (6 枚) に変化さ せて, コンクリート表面の評価では $20 \mathrm{~cm}$ ピッチ, at $1 \mathrm{~m}$ の評価では $40 \mathrm{~cm}$ ピッチで実施した。

\section{(2) 解析結果}

(a) 通常養生コンクリート

中心位置 $(\mathrm{C})$ に打ける中性子線量率を第24図に, C/E を 第13表に示す。中心位置 $(\mathrm{C})$ では, 厚さ $120 \mathrm{~cm}$ のコンク リート表面を除いて $(\mathrm{C} / \mathrm{E}$ は 1.5$)$, コンクリート表面およ び at $1 \mathrm{~m}$ において計算值と測定值は約 $20 \%$ 以内で一致し た。

(b) 乾燥養生コンクリート

中心位置 $(\mathrm{C})$ に打ける中性子線量率を第25図に, C/E を

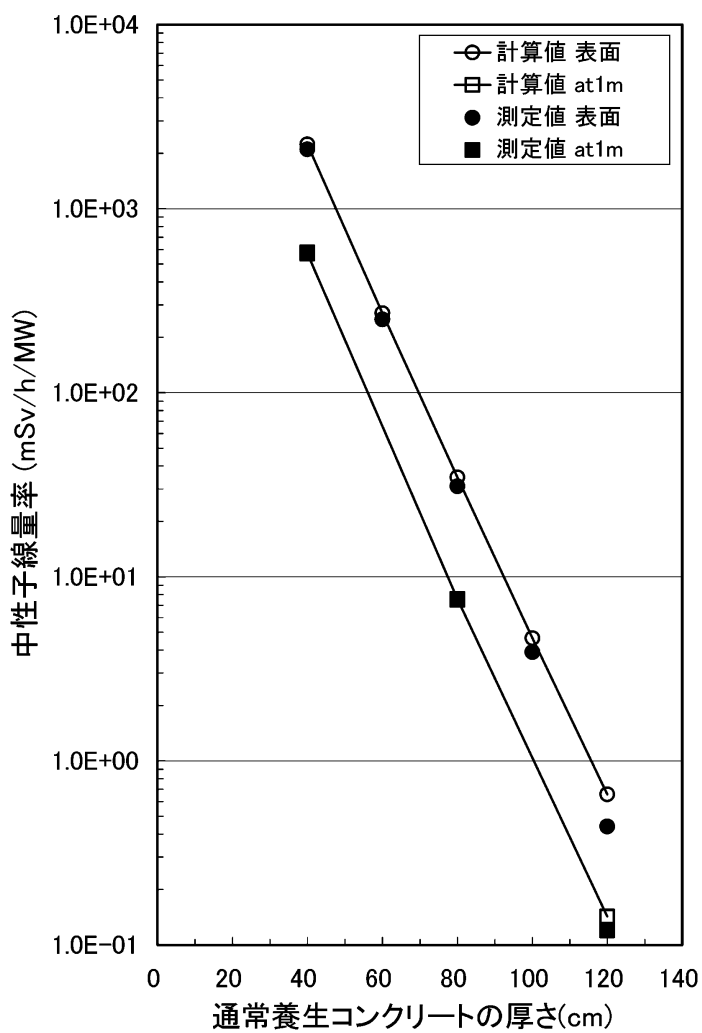

第24図＼cjkstart通常養生コンクリート透過後の中性子線量率〔測定方 向 : 中心 $(\mathrm{C})]$

第13表＼cjkstart通常養生コンクリート透過後の中性子線量率

\begin{tabular}{|c|c|c|c|c|c|c|}
\hline \multirow{3}{*}{ 供試体厚さ $(\mathrm{cm})$} & \multicolumn{6}{|c|}{ 中性子線量率 (mSv/h/MW) } \\
\hline & \multicolumn{3}{|c|}{ 測定位置 : 表面 } & \multicolumn{3}{|c|}{ 測定位置 : at $1 \mathrm{~m}$} \\
\hline & $\frac{\text { 測定值 }}{(\mathrm{E})}$ & $\begin{array}{c}\text { 計算値 } \\
\text { (1) }\end{array}$ & $(\mathrm{C} / \mathrm{E})$ & $\begin{array}{l}\text { 測定値 } \\
(\mathrm{E})\end{array}$ & 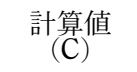 & $(\mathrm{C} / \mathrm{E})$ \\
\hline 40 & $2.1 \mathrm{E}+03$ & $2.2 \mathrm{E}+03$ & 1.06 & $5.8 \mathrm{E}+02$ & $5.7 \mathrm{E}+02$ & 0.98 \\
\hline 60 & $2.5 \mathrm{E}+02$ & $2.7 \mathrm{E}+02$ & 1.08 & & - & \\
\hline 80 & $3.1 \mathrm{E}+01$ & $3.5 \mathrm{E}+01$ & 1.12 & $7.5 \mathrm{E}+00$ & $7.6 \mathrm{E}+00$ & 1.01 \\
\hline 100 & $3.9 \mathrm{E}+00$ & $4.6 \mathrm{E}+00$ & 1.19 & & - & \\
\hline 120 & $4.4 \mathrm{E}-01$ & $6.6 \mathrm{E}-01$ & 1.50 & $1.2 \mathrm{E}-01$ & $1.4 \mathrm{E}-01$ & 1.19 \\
\hline
\end{tabular}


第14表に示す。中心位置 (C)では, 計算值と測定值は約 20 $\%$ 以内で一致した。

\section{V. 結 語}

\section{1. 相互遮へ(効果実験}

相互遮へい効果実験では, 測定誤差は中性子線量率で約 5〜 15\%である。計算值は約 $20 \%$ 以内で測定值と一致して おり，MCNPコードにより精度よく評価できることを確 認した。また，キャスク配列による相互遮へい効果は有意 であり，遮へい設計の合理化の面でも有効であること，打 よび MCNP コードによる安全裕度を考慮した適切な金属 キャスクのモデル化の検討が可能であることを確認した。

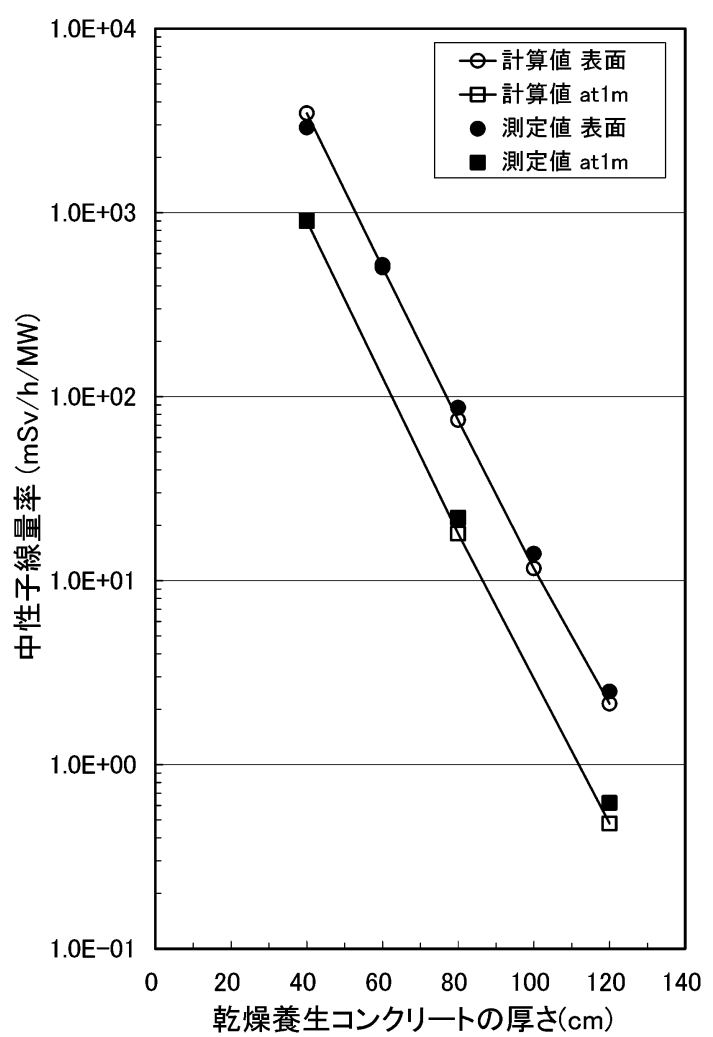

第25図 乾燥養生コンクリート透過後の中性子線量率 [測定方 向 : 中心 $(\mathrm{C})]$

\section{2. ダクトストリーミング実験}

ダクトストリーミング実験では, 測定誤差は中性子線量 率で約 5 15\%である。計算值は約 $30 \%$ 以内で測定值と一 致しており, MCNPコードにより精度よく評価できるこ とを確認した。また，コンクリート製ルーバーの減衰効果 は有意であり, 遮へい設計の合理化の面でも有効であるこ とを確認した。

\section{3. コンクリート深層透過実験}

コンクリート深層透過実験では, 平板中央での測定誤差 は約 $10 \%$ 以内である。計算值は，厚さが $40 \mathrm{~cm}$ から 120 $\mathrm{cm}$ までの水分含有量の異なるコンクリートにおいて, 約 $20 \%$ 以内で測定值と一致しており，MCNPコードにより 精度よく評価できることを確認した。

\section{4.まとめ}

MCNP コードによる線量評価の検討課題に対して, 本 研究に拈いて適切なベンチマーク実験と 3 次元モンテカ ルロ評価手法・MCNP コードによる計算結果との比較を 行い, 上記 3 つの課題に対して $30 \%$ 以内の計算精度であ ることが確認された。これは現行の許認可申請等で使用さ れている輸送計算コードのベンチマーク実験解析 ${ }^{16)}$ と比 較しても, 同等またはそれ以上の計算精度を有しているこ とから，十分な計算精度を得られることが検証できた。

以上のことから，3 次元モンテカルロ評価手法 · MCNP コードは, 中間貯蔵施設の遮へい設計および線量評価へ適 用する評価手法および解析コードとして十分な妥当性を有 していることがわかった。

本研究は, 東京電力株, 関西電力秼を幹事とする北海道 電力秼, 東北電力秼, 中部電力秼, 北陸電力秼, 中国電力 陎, 四国電力秼, 九州電力侏, 日本原子力発電侏, 電源開 発侏との共同研究で実施した。

\section{一参考文献一}

1) W. W. Engle Jr., ANISN, A, One-Dimensional Discrete Ordinates Transport Code with Anisotropic Scattering, K-1693 (1967).

2) RSIC Computer Code Collection, DOT-3.5 Two-Dimensional

第14表＼cjkstart乾燥養生コンクリート透過後の中性子線量率

\begin{tabular}{|c|c|c|c|c|c|c|}
\hline \multirow{3}{*}{ 供試体厚さ (cm) } & \multicolumn{6}{|c|}{ 中性子線量率 (mSv/h/MW) } \\
\hline & \multicolumn{3}{|c|}{ 測定位置 : 表面 } & \multicolumn{3}{|c|}{ 測定位置 : at $1 \mathrm{~m}$} \\
\hline & $\begin{array}{c}\text { 測定值 } \\
(\mathrm{E})\end{array}$ & $\begin{array}{c}\text { 計算值 } \\
\text { (C) }\end{array}$ & $(\mathrm{C} / \mathrm{E})$ & $\begin{array}{c}\text { 測定值 } \\
(\mathrm{E})\end{array}$ & $\begin{array}{c}\text { 計算值 } \\
\text { (C) }\end{array}$ & $(\mathrm{C} / \mathrm{E})$ \\
\hline 40 & $2.9 \mathrm{E}+03$ & $3.5 \mathrm{E}+03$ & 1.20 & $9.0 \mathrm{E}+02$ & $9.0 \mathrm{E}+02$ & 1.00 \\
\hline 60 & $5.2 \mathrm{E}+02$ & $5.0 \mathrm{E}+02$ & 0.97 & & - & \\
\hline 80 & $8.7 \mathrm{E}+01$ & $7.5 \mathrm{E}+01$ & 0.86 & $2.2 \mathrm{E}+01$ & $1.8 \mathrm{E}+01$ & 0.82 \\
\hline 100 & $1.4 \mathrm{E}+01$ & $1.2 \mathrm{E}+01$ & 0.83 & & - & \\
\hline 120 & $2.5 \mathrm{E}+00$ & $2.1 \mathrm{E}+00$ & 0.86 & $6.2 \mathrm{E}-01$ & $4.8 \mathrm{E}-01$ & 0.77 \\
\hline
\end{tabular}


Discrete Ordinates Radiation Transport Code, CCC-276 (1975).

3) 財原子力安全研究協会, 使用済燃料中間貯蔵施設の直接線 . スカイシャイン線量の評価手法(金属キャスク方式)，リサイ クル燃料資源貯蔵施設安全設計・評価検討専門委員会 スカ イシャイン線量評価検討ワーキンググループ(1999).

4) J. F. Briesmeister, ed., $M C N P-A$ General Monte Carlo NParticle Transport Code, Version 4B, Los Alamos National Laboratory Report, LA-12625-M (1997).

5) J. F. Briesmeister, ed., $M C N P-A$ General Monte Carlo $N-$ Particle Transport Code, Version 4C, Los Alamos National Laboratory Report, LA-13709-M (2000).

6) U. S. Nuclear Regulatory Commission, Standard Review Plan for Spent Fuel Dry Storage Facilities, NUREG-1567 (2000).

7) W. M. Boehnke, Safety Analysis Report for Packaging (Onsite) Steel Waste Package, HNF-4763, Rev. 0 (2000).

8) D. A. Brownson, Waste Package Design Methodology Report, TDR-MGR-MD-000006, Rev. 01 (2001).

9) K. T. Tsang, P. Pattantyus, "Direct and scatter radiation from a CANSTOR module," Proc. 1998 ANS Radiat. Prot. Shield. Div. Top. Conf. Technol. New Century Vol. 1, ANS Radiation Protection and Shielding Division Topical Conference (5th) Nashville, Tenn. (1998).
10) E. L. Redmond II, "Methodology for calculating dose rates from storage cask arrays using MCNP," Trans. Am. Nucl. Soc., 77, 332-333 (1997).

11) W. T. Urban, R. R. Roberts, G. P. Estes et al. "Application of MCNP to storage facility dose rate assessment," Radiat. Prot. Shield. Vol. 1, Topical Meeting on Radiation Protection and Shielding, No. Falmouth, Mass., 440-450 (1996).

12) F. Lemay, "MCNP calculations for the licensing of a spent fuel dry storage facility," Proc. 8th Int. Conf. Radiat. Shield. 1994 Vol. 2, International Conference on Radiation Shielding (8th) Arlington, Tex., 765-771 (1994).

13) K. Mio, T. Kurashige, T. Kosako, "The shielding effect of iron louvers for neutrons and gamma rays," Nucl. Technol., 136, 63-75 (2001).

14) K. Mio, T. Kurashige, T. Kosako, "Experimental and calculational estimation of radiation streaming through a single bent duct with and without a louver type iron shield," Proc. 8th Int. Con. Radiat. Shield., 2 (1994).

15) K. Oishi, Y. Ikeda, H. Maekawa et al. "Experiment and analysis of neutron spectra in a concrete assembly bombarded by 14-MeV neutrons," Nucl. Sci. Eng., 103, 46-58 (1989).

16) 社日本原子力学会, 中性子遮蔽ハンドブック, 放射線挙動工 学研究専門委員会, 中性子遮蔽設計法ワーキング・グループ. 